\title{
Experimental Investigation of the Intermediates of Isooctane During Ignition
}

\author{
X. HE, S. M. WALTON, B. T. ZIGLER, M. S. WOOLDRIDGE, A. ATREYA \\ Department of Mechanical Engineering, University of Michigan, Ann Arbor, MI 48109-2125
}

Received 24 August 2006; revised 1 February 2007; accepted 1 February 2007

DOI 10.1002/kin.20254

Published online in Wiley InterScience (www.interscience.wiley.com).

\begin{abstract}
Direct measurements of intermediates of ignition are challenging experimental objectives, yet such measurements are critical for understanding fuel decomposition and oxidation pathways. In the current work, a new gas-sampling system is used to provide quantitative discrete measurements of 30 hydrocarbon and oxygenate species during rapid compression facility studies of isooctane ignition. Two target conditions and equivalence ratios (based on molar fuel to oxygen ratio) were studied ( $\mathrm{P}=5.2 \mathrm{~atm}, \mathrm{~T}=1000 \mathrm{~K}, \phi=0.4$ and $\mathrm{P}=4.8 \mathrm{~atm}$, $\mathrm{T}=975 \mathrm{~K}, \phi=1.2$ ). The results are compared with model predictions that use the detailed reaction mechanism developed by Curran et al. (Combust Flame 2002, 129, 253-280). In general, the model predictions are in excellent agreement with the experimental data, including several trace species. Isobutene $\left(\mathrm{i}-\mathrm{C}_{4} \mathrm{H}_{8}\right)$ and propene $\left(\mathrm{C}_{3} \mathrm{H}_{6}\right)$ were the major olefin species identified in the experiments. The results are consistent with an intermediate temperature reaction path sequence, where isooctane is consumed by $\mathrm{H}$-atom abstraction to yield isooctyl radicals that undergo $\beta$-scission to form olefin and alkyl radical species. (c) 2007 Wiley Periodicals, Inc. Int J Chem Kinet 39: 498-517, 2007
\end{abstract}

\section{INTRODUCTION}

Fuel-lean, low-temperature conditions, where temperatures are below $1100 \mathrm{~K}$, are the focus of numerous advanced combustion technologies, including homogeneous charge compression ignition (HCCI) internal combustion engine strategies and modern gas turbine design. In these premixed and other combustion systems, the reaction kinetics are often rate limiting in terms of ignition properties and reaction progress. As a consequence, many experimental, computational, and analytical studies of hydrocarbon kinetics have focused on improving our understanding of the fundamental re-

Correspondence to: Margaret Wooldridge; e-mail: mswool@ umich.edu.

Contract grant sponsor: U.S. Department of Energy via the HCCI University Consortium.

(c) 2007 Wiley Periodicals, Inc. action kinetics of key reference fuels such as isooctane [1-17] and $n$-heptane $[1-7,11,17-20]$ at conditions relevant to these advanced technologies (i.e., lean equivalence ratios, intermediate and low temperatures, and high pressures). The results of these investigations have led to dramatic progress, expanding the experimental database of characteristic combustion parameters (e.g., ignition delay time, $\tau_{\text {ign }}$ ) and further developing detailed reaction chemistry toward more accurate predictions of combustion performance.

Ignition delay time measurements are important for developing predictive capabilities for ignition as a function of mixture and state conditions. Ignition delay time data are also one valuable means for validating detailed, skeletal, and reduced reaction kinetics. Experimental studies of ignition delay time have quantified the ignition behavior of isooctane $[1,2,5,9,13,14,21,22], n$-heptane $[1,2,4-6,19]$, and (4)WILEY 
other reference fuels over a broad range of temperatures, pressures, and compositions. Experimental determination of ignition properties of fuel blends and fuel surrogate mixtures has also been of considerable interest $[9,13,19,23,24]$.

Measurements that complement and augment kinetic benchmarks like $\tau_{\text {ign }}$ data are species concentration data. Such experimental results are vital because they provide direct insight into the reaction pathways significant during fuel oxidation. Quantitative measurements of the evolution of radical and hydrocarbon (HC) concentrations provide explicit knowledge of the species formed during radical pool growth and fuel oxidation. For example, experimental investigations of the hydroxyl radical $(\mathrm{OH})$ have elucidated the key role of hydrogen/oxygen kinetics at low [15] and high [21,22] temperatures during isooctane ignition. The study of intermediate $\mathrm{HC}$ species is of particular importance for understanding the reaction paths controlling fuel consumption; however, quantifying $\mathrm{HC}$ intermediates experimentally is often difficult because of the sampling and analytical methods typically required. As a consequence, relatively few $\mathrm{HC}$ speciation data are currently available in the literature for a limited range of conditions and fuels.

Speciation studies of the HC intermediates of isooctane oxidation include the rapid compression facility (RCF) studies by Minetti and coworkers [5], the jetstirred flow reactor studies by D'Anna et al. [25] and Dagaut et al. [3], the plug flow reactor study by Dryer and Brezinsky [26], and the high-pressure flow reactor study by Chen et al. [10]. Each of these groups quantified the intermediate $\mathrm{HC}$ species concentrations during isooctane oxidation. In addition, the flow reactor study by Callahan et al. [4] presented measurements of the major products of combustion during isooctane oxidation. These experimental data have provided key insights into the decomposition and oxidation pathways important at conditions relevant to engine operation; however, most of these studies focused on stoichiometric isooctane/air mixtures.

The studies by Dagaut et al. [3] and Chen et al. [10] considered lean equivalence ratio conditions that are of considerable interest to modern engine and combustor design. Dagaut et al. [3] measured hydrocarbon species over the equivalence ratio range of $\phi=0.3-$ 1.5 and temperature range 550-1150 $\mathrm{K}$ during highpressure $(10 \mathrm{~atm})$ reactor studies of isooctane. Chen et al. [10] conducted high-pressure (3, 6, and 9 atm) flow reactor studies where they obtained speciation data during very lean $(\phi=0.05)$ isooctane oxidation over the temperature range 915-950 K. Equivalence ratio, temperature, pressure, and dilution all have pronounced effects on the ignition kinetics of isooctane
$[1,11,10]$. Consequently, the objective of the current work was to clarify the reaction pathways important during isooctane ignition at conditions complementary to the previous HC speciation studies, expanding our understanding of the detailed reaction kinetics. Specifically, the current work focuses on $\mathrm{HC}$ and oxygenated $\mathrm{HC}$ measurements obtained during RCF experiments conducted at $\phi=0.4, T \cong 1000 \mathrm{~K}, P \cong 5 \mathrm{~atm}$ and at $\phi=1.2, T \cong 975 \mathrm{~K}, P \cong 5 \mathrm{~atm}$. These conditions have direct relevance to modern low-temperature combustion strategies.

The technical approach used to meet the objective of the study was to isolate the reaction kinetics of interest using the University of Michigan Rapid Compression Facility (UM RCF). The uniform conditions and long test times provided by the UM RCF are critical to the successful speciation of $\mathrm{HC}$ intermediates during isooctane ignition. Specifically, gases are sampled from the core region of the test section of the RCF using a custom designed and built gas-sampling system. The gases are then analyzed using gas chromatography. Detailed descriptions of the sampling and analytical procedures are provided below. The results for the HC species profiles are discussed in terms of the major reaction pathways for isooctane consumption and compared with model predictions based on the detailed reaction mechanism developed by Curran et al. [11] for isooctane combustion.

\section{EXPERIMENTAL APPROACH}

\section{Rapid Compression Facility}

All experiments were conducted using the UM RCF. The UM RCF is an innovative and unique experimental apparatus that can be used to create uniform hightemperature $(T=500-3000 \mathrm{~K})$ and high-pressure $(P=0.5-60 \mathrm{~atm})$ conditions [27] that are directly applicable to many combustion systems. A detailed description of the UM RCF, the operating procedure, and the results of studies characterizing the performance can be found in $[14,15,27-29]$. Briefly, the UM-RCF consists of five major components: the driver section, the driven section, the test manifold, the sabot (i.e., the free piston), and the hydraulic control valve assembly. For each experiment, the sabot is located at the upstream end of the driven section; the driven section is evacuated with a diffusion pump; and the driver section is filled with high-pressure air. The driver and driven sections are separated by the hydraulic control valve assembly and a scored sheet of polyester film $\left(0.05 \mathrm{~mm}\right.$ thick, MYLAR $\left.{ }^{\circledR}\right)$. After filling the driven section with the prepared test gas mixture, a globe valve is opened (using the hydraulic control valve assembly), 
permitting the high-pressure driver gas to break the polyester film, enter the driven section, and rapidly accelerate the sabot. The test gas mixture is compressed ahead of the sabot. The sabot comes to rest in the test manifold when the nosecone seals via an annular interference fit with the extension section. Note that the nosecone does not rebound and is firmly seated throughout each experiment. The core region of the test gases is sealed in the test manifold, while the cooler gases near the walls are sealed in the shoulder region of the convergent section. The compression process can be considered isentropic for the gases in the core region of the driven section, and high-temperature and high-pressure conditions are created in the test section as a result of the compression process.

For the current study, the test section was instrumented with a piezoelectric transducer (6041AX4, Kistler, Amherst, NY) and charge amplifier (5010B, Kistler, Amherst, NY) for pressure measurements, and a stainless steel end wall equipped with the gas-sampling system. Each experiment was designed to target one of two conditions, corresponding to one lean and one rich isooctane/air mixture. The test gas mixtures were made in a dedicated mixing tank, and the mixture composition was determined by measurement of the relative partial pressures of the gas-phase components.

\section{Gas-Sampling System}

A schematic of the UM RCF test section and the gas-sampling system is shown in Fig. 1. The gassampling system consists of a sampling probe, a fast-acting solenoid valve (MHE2-MS1H-3/2G-M7-K, Festo, Hauppauge, NY), two needle valves, a vacuum pump, and sample tank. The sample tank is equipped with a septum port for gas extraction and a pressure sensor. The sampling probe ( $2 \mathrm{~mm}$ inner diameter) is installed on the RCF end wall. The open end of the probe is located at the center of the test section, $15 \mathrm{~mm}$ from the end wall. The other end of the sampling probe is connected to the fast-acting solenoid valve, which is capable of opening and closing within $2 \mathrm{~ms}$. The total volume of the sampling tank is approximately 18.5 $\mathrm{cm}^{3}$. When compared to the volume of the test section $\left(150 \mathrm{~cm}^{3}\right)$, approximately $1.6 \%$ of the test gas is sampled during each experiment. The two needle valves are used to isolate the contents of the sampling tank after each experiment. A piezoresistive pressure sensor (type 4045A2, Kistler, Amherst, NY) and a piezoresistive amplifier (type 4618A0, Kistler, Amherst, NY) are used to record the pressure in the sampling tank. The vacuum pump is used to evacuate the sampling tank before each experiment.

Representative gases are acquired by rapidly opening and closing the solenoid valve of the gas-sampling system during an RCF experiment. Triggering electronics based on the location of the sabot are used to set the timing of the solenoid valve relative to the end of compression. The time delay between the trigger signal and the signal to the solenoid valve is used to vary the start of the gas-sampling event. The sampling interval was kept constant for all experiments at a value of $2.1 \pm 0.3 \mathrm{~ms}$.

In order to pressurize the sample for injection into the gas chromatographs (GCs), either a customdesigned syringe or a commercially available syringe (PS-050035, Valco, Houston, TX) with a pressure lock is used. After a portion of the gas sample is extracted through the septum on the sampling chamber into the

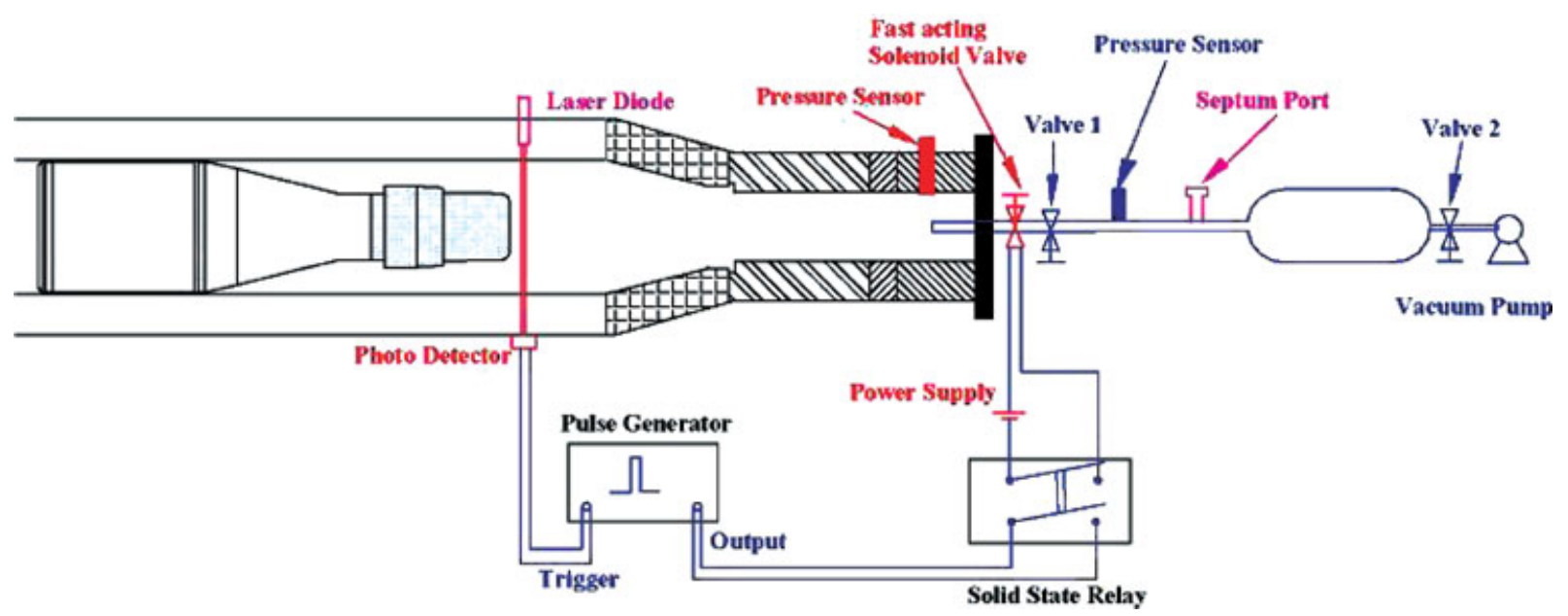

Figure 1 Experimental schematic of UM RCF test manifold and rapid gas-sampling apparatus. [Color figure can be viewed in the online issue, which is available at www.interscience.wiley.com.] 
syringe, the pressure lock is closed. The plunger of the syringe is then used to pressurize the gas in the syringe. The custom-designed syringe can be heated to a maximum temperature of $115^{\circ} \mathrm{C}$, whereas the maximum operating temperature of the Valco syringe is $55^{\circ} \mathrm{C}$. The sampling tank can also be heated to prevent condensation losses. Note the partial pressure of water is expected to be low (a maximum of $10 \%$ of the saturated vapor pressure at room temperature) at the conditions in the sampling tank, so condensation effects are not expected to be significant for water. However, experiments were conducted at the $\phi=0.4$ conditions with and without heating the custom-designed syringe and the sampling chamber to evaluate condensation effects. The data were in excellent agreement. The sampling chamber and syringe were not heated for the experiments conducted at the $\phi=1.2$ conditions.

Quantitative measurements of the species sampled from the UM RCF require knowledge of the dilution of the sample gas that results from the sampling method used. In other words, because of the existence of a dead volume in the sampling system, the mole fractions calculated from the gas chromatograms are not the species mole fractions of the gases in the core region of the RCF. The dead volume is defined as the total volume in the sampling probe and the fast-sampling valve exposed to the reactant gases. Here the entire contents of the sampling probe $(2 \mathrm{~mm}$ i.d., $40 \mathrm{~mm}$ length) were considered quenched, as well as the volume of the valve that was approximated as a column with $5 \mathrm{~mm}$ i.d. and $4 \mathrm{~mm}$ length. The dead volume was estimated as $0.2 \mathrm{~cm}^{3}$ with an uncertainty of $\pm 10 \%$ based on the convoluted geometry of the valve. During the compression process, the test gas mixture enters the sampling probe and the fast-sampling valve from the core region. Because of the large surface-area-to-volume ratio, the gas temperature in the dead volume is low, and the gases are chemically quenched in this region. When the fast-sampling valve is opened, these cold, unreacted gases are transported into the sampling tank, thereby diluting the gas sample obtained from the core region. The dilution ratio, $\zeta$, is calculated using the following relation:

$$
\zeta=\frac{P_{\text {eff }} \cdot V_{\text {dead }}}{T_{\text {dead }}} \cdot \frac{T_{\text {sampling }}}{P_{\text {sampling }} \cdot V_{\text {sampling }}}
$$

where $P_{\text {eff }}$ is the effective pressure of the experiment, $V_{\text {dead }}$ is the total dead volume in the sampling probe and the fast-acting valve, $T_{\text {dead }}$ is the average gas temperature in the dead volume, $P_{\text {sampling }}$ is the final pressure in the sampling chamber, $V_{\text {sampling }}$ is the total volume of the sampling chamber $\left(\sim 18.5 \mathrm{~cm}^{3}\right)$, and $T_{\text {sampling }}$ is the final gas temperature in the sampling tank. $T_{\text {dead }}$ is estimated to be about $350 \mathrm{~K}$. For typical conditions in the RCF experiments conducted, the dilution ratio is $\zeta \cong 30 \%$. The species mole fractions (excluding isooctane) in the core region, $\chi_{\text {core }}$, are then determined by

$$
\chi_{\text {core }}=\frac{\chi_{\text {sampling }}}{1-\zeta}
$$

where $\chi_{\text {sampling }}$ is the species mole fraction in the sampling chamber determined from the gas chromatograms.

\section{Gas Chromatography}

Four gas chromatographs (GCs) were used to identify and quantify the hydrocarbon species present during ignition of the isooctane mixtures. Prepurified helium and argon were used as carrier gases. The carrier gases were further purified using adsorbents to remove water, hydrocarbons, and oxygen. The injection port consisted of a rubber septum through which the syringe needle was inserted for injecting the sample into the 5 - $\mu \mathrm{L}$ sample loop. A temperature-controlled 10-port valve was used to direct the sample into each of the chromatographs.

Table I summarizes the configuration of the GC system including column selection, oven temperature program, detector type, carrier gas selection, carrier gas flow rate or pressure, and GC events. Permanent gases were separated using two capillary columns in series in GC1. Oxygenates were separated using GC2. To prevent interference due to particles that could be emitted from the Lowox column, a particle trap (CP4017, Varian, Palo Alto, CA) was installed after the column and before the detector in $\mathrm{GC} 2$. For measurement of small hydrocarbons $\left(\mathrm{C}_{1}-\mathrm{C}_{5}\right)$, an $\mathrm{Al}_{2} \mathrm{O}_{3} / \mathrm{Na}_{2} \mathrm{SO}_{4}$ capillary column was used in GC3. Two columns were installed in GC4. An RTX-1 capillary column with a flame ionization detector (FID) was used to separate and measure large hydrocarbons $\left(\mathrm{C}_{5}-\mathrm{C}_{8}\right)$. A ShinCarbon packed column and TCD detector were configured to measure the concentration of $\mathrm{H}_{2}$; however, the $\mathrm{H}_{2}$ levels were below the detectivity limits for this study. The four GCs were operated simultaneously, and the signals from the detectors were recorded using a high-resolution data acquisition system (PXI 4472, National Instruments, Austin, TX) with a sampling rate of $10 \mathrm{~Hz}$.

$\mathrm{GC}$ analysis included the identification of species and concentration measurements for each compound, where calibration standards could be established. Species were identified by comparison of the experimental chromatograms with GC databases, previously published GC results for isooctane combustion $[3,10]$, 
Table I Summary of GC Configurations Used

\begin{tabular}{|c|c|c|c|c|c|}
\hline Designation & GC1 & $\mathrm{GC} 2$ & GC3 & \multicolumn{2}{|c|}{ GC4 } \\
\hline GC model & PE Autosystem GC & PE Autosystem GC & PE Autosystem GC & \multicolumn{2}{|c|}{ PE Clarus 500GC } \\
\hline $\begin{array}{l}\text { Column(s) } \\
\text { (source, model) }\end{array}$ & $\begin{array}{c}\text { CP-Molsieve 5A } \\
\text { (Varian, CP7538) } \\
\text { CP-Porobond Q } \\
\text { (Varian, CP7354) }\end{array}$ & $\begin{array}{c}\text { CP-Lowox } \\
\text { (Varian, CP8587) }\end{array}$ & $\begin{array}{l}\mathrm{CP}-\mathrm{Al}_{2} \mathrm{O}_{3} / \mathrm{Na}_{2} \mathrm{O}_{4} \\
(\text { Varian, } \mathrm{CP} 7568)\end{array}$ & $\begin{array}{c}\text { RTX-1 } \\
\text { (Resteck, 10157) }\end{array}$ & $\begin{array}{c}\text { Shin-Carbon } \\
\text { (Resteck, 19808) }\end{array}$ \\
\hline Species targeted & $\mathrm{N}_{2}, \mathrm{O}_{2}, \mathrm{Ar}, \mathrm{CO}_{2}, \mathrm{CO}, \mathrm{CH}_{4}$ & Oxygenates & $\mathrm{C} 1-\mathrm{C} 5$ & $\mathrm{C}_{5}-\mathrm{C}_{8}$, Oxygenates & $\mathrm{H}_{2}$ \\
\hline Carrier gas & Helium & Helium & Helium & Helium & Argon \\
\hline $\begin{array}{l}\text { Flow rate or pressure } \\
\text { Detector }\end{array}$ & $4.5 \mathrm{~mL} / \mathrm{min}$ & $3.2 \mathrm{~mL} / \mathrm{min}$ & $4.5 \mathrm{~mL} / \mathrm{min}$ & $12.1 \mathrm{psi}$ & $10.2 \mathrm{~mL} / \mathrm{min}$ \\
\hline Type & TCD & FID & FID & FID & TCD \\
\hline Temperature & $300^{\circ} \mathrm{C}$ & $300^{\circ} \mathrm{C}$ & $300^{\circ} \mathrm{C}$ & $300^{\circ} \mathrm{C}$ & $250^{\circ} \mathrm{C}$ \\
\hline Temperature program & $\rightarrow 80^{\circ} \mathrm{C}(40 \mathrm{~min})$ & $\begin{array}{c}120^{\circ} \mathrm{C}(12 \mathrm{~min}) \\
\rightarrow 10^{\circ} \mathrm{C} / \mathrm{min} \\
\rightarrow 200^{\circ} \mathrm{C}(15 \mathrm{~min})\end{array}$ & $\begin{array}{c}80^{\circ} \mathrm{C}(10 \mathrm{~min}) \\
\rightarrow 5^{\circ} \mathrm{C} / \mathrm{min} \\
\rightarrow 140^{\circ} \mathrm{C}(18 \mathrm{~min})\end{array}$ & \multicolumn{2}{|c|}{$50^{\circ} \mathrm{C}(40 \mathrm{~min})$} \\
\hline
\end{tabular}

and by calibration tests performed for reference compounds. For the calibration tests, high-purity reference chemicals and standard gas mixtures were obtained, and the retention times of these chemicals were documented for each GC. The peak areas of the chromatogram features were used to establish the calibrations for absolute concentration.

\section{RESULTS}

Figure 2 presents typical experimental results of the pressure time histories in the RCF test section and the sampling chamber for a fuel-lean condition where the equivalence ratio was $\phi=0.4$ (based on the molar ratios of fuel to oxygen). The reactant mixture composition on a mole basis was $0.53 \%$ isooctane, $16.6 \%$ $\mathrm{O}_{2}, 9.8 \%$ Ar, and $73.07 \% \mathrm{~N}_{2}$. The solid line in Fig. 2 represents the pressure profile in the test section. The dashed line represents the pressure profile in the sampling tank.

The pressure profile for the RCF test section indicates a smooth compression process until the end of compression when the sabot seats in the test section. At the end of compression, some fluctuations in pressure occur as a result of pressure waves traveling the axial length of the test section. These pressure oscillations are small (less than $3 \%$ of the end of compression pressure) and do not have a significant effect on ignition behavior. After a period of time, the isooctane ignites leading to a rapid increase in the pressure. For each experiment, the ignition delay time $\left(\tau_{\text {ign }}\right.$, defined as the difference between the end of compression and the start of ignition) was determined using the pressure time histories. Further details on the determination of $\tau_{\text {ign }}$ from the pressure data can be found in He et al. [14].

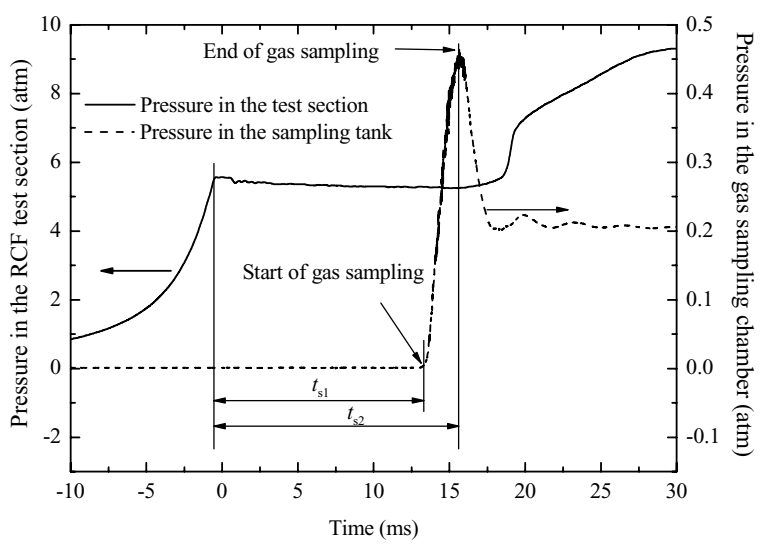

Figure 2 Typical pressure time histories in the test section and sample chamber during an ignition experiment for conditions of $P_{\text {eff }}=5.34 \mathrm{~atm}, T_{\text {eff }}=1002 \mathrm{~K}$, and $\phi=0.4,\left(\mathrm{~N}_{2}+\right.$ $\mathrm{Ar}) / \mathrm{O}_{2}=5$.

The effective pressure for each experiment, $P_{\text {eff }}$, was defined as the time-integrated average of the pressure in the test section from the maximum pressure due to compression to the minimum pressure before ignition. The effective temperature was determined using the effective pressure and by numerical integration of the isentropic relation:

$$
\int_{T_{0}}^{T_{\text {eff }}} \frac{\gamma}{\gamma-1} \mathrm{~d} \ln T=\ln \left(\frac{P_{\text {eff }}}{P_{0}}\right)
$$

where $P_{0}$ is the charge pressure, $T_{0}$ is the initial temperature (typically $298 \mathrm{~K}$ ), and $\gamma$ is the temperaturedependent ratio of the specific heats of the unreacted test gas mixture, which was determined using the NASA thermodynamic data base [30].

The key events during gas sampling can be identified from the pressure profile of the sample chamber. 
As seen in Fig. 2, the pressure in the chamber sharply increases when the fast-acting valve is opened. The increase in pressure lasts for about $2 \mathrm{~ms}$, which is the time interval of the pulse signal. The expansion of the gas sample from the core region of the RCF test section into the evacuated sampling volume rapidly (within $2 \mathrm{~ms}$ ) reduces the gas temperature from 1000 $\mathrm{K}$ to less than $525 \mathrm{~K}$ (as estimated based on isentropic expansion), which is considered sufficient to chemically quench the sample. After the fast-acting valve is closed, the pressure in the sample chamber decreases due to heat transfer from the sample gas to the sample chamber walls ( $T_{\text {wall }} \cong 300 \mathrm{~K}$ ). The slight oscillation in the sample chamber pressure data is due to pressure waves traveling through the sampling chamber.

Figure 3 presents the gas chromatograms corresponding to the experimental results presented in Fig. 2. A summary of the species identified in the study, the corresponding molecular formulae and structure, and the GC used for detection is presented in Table II.
The data from GC1 (Fig. 3a) were used exclusively to accurately quantify $\mathrm{CO}$ concentrations. Although $\mathrm{CH}_{4}$ was separated in this chromatogram, more accurate measurements of $\mathrm{CH}_{4}$ concentration were available using GC3. Carbon dioxide was identified in the GC1 chromatograms (as seen in Fig. 3a); however, because the $\mathrm{CO}_{2}$ peak was located at a point where there was a shift in the GC baseline the results were subject to high uncertainties. As a consequence, the $\mathrm{CO}_{2}$ data are not presented in this work.

The GC2 chromatogram indicates that the small hydrocarbons $\left(\mathrm{C}_{1}-\mathrm{C}_{8}\right)$ elute rapidly (within $2 \mathrm{~min}$; see Fig. 3b), and the oxygenates are well isolated with good signal-to-noise ratios. Note that the baseline shift observed in Fig. 3b after $12 \mathrm{~min}$ is due to the temperature program used. Eight oxygenates were identified (see Fig. $3 b$ ): acetaldehyde $\left(\mathrm{CH}_{3} \mathrm{CHO}\right)$, propionaldehyde $\left(\mathrm{C}_{3} \mathrm{H}_{6} \mathrm{O} 1-2\right)$, methacrolein $\left(\mathrm{i}-\mathrm{C}_{3} \mathrm{H}_{5} \mathrm{CHO}\right)$, isobutyraldehyde $\quad\left(\mathrm{i}-\mathrm{C}_{3} \mathrm{H}_{7} \mathrm{CHO}\right), \quad$ pivaldehyde $\left(\mathrm{t}-\mathrm{C}_{4} \mathrm{H}_{9} \mathrm{CHO}\right)$, acetone $\left(\mathrm{CH}_{3} \mathrm{COCH}_{3}\right)$, allyl alcohol
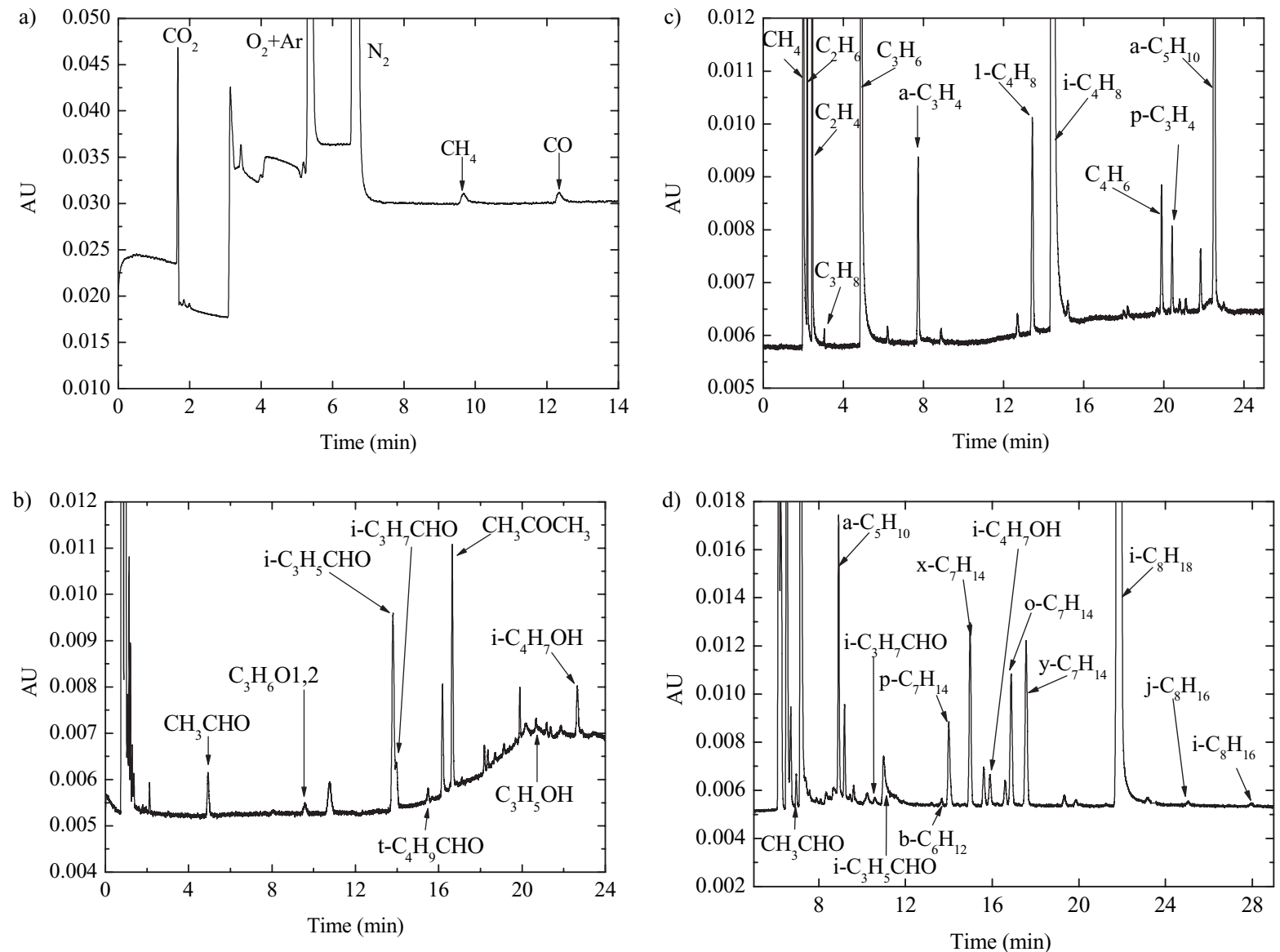

Figure 3 Typical chromatogram data for (a) stable gases (GC1), (b) oxygenates (GC2), (c) small hydrocarbons (GC3), and (d) large hydrocarbons (GC4). Experimental conditions are those of Fig. 2: $P_{\text {eff }}=5.34 \mathrm{~atm}, T_{\text {eff }}=1002 \mathrm{~K}$, and $\phi=0.4$, $\left(\mathrm{N}_{2}+\right.$ $\mathrm{Ar}) / \mathrm{O}_{2}=5$. 
Table II Species Identified and Measured in the Current Work

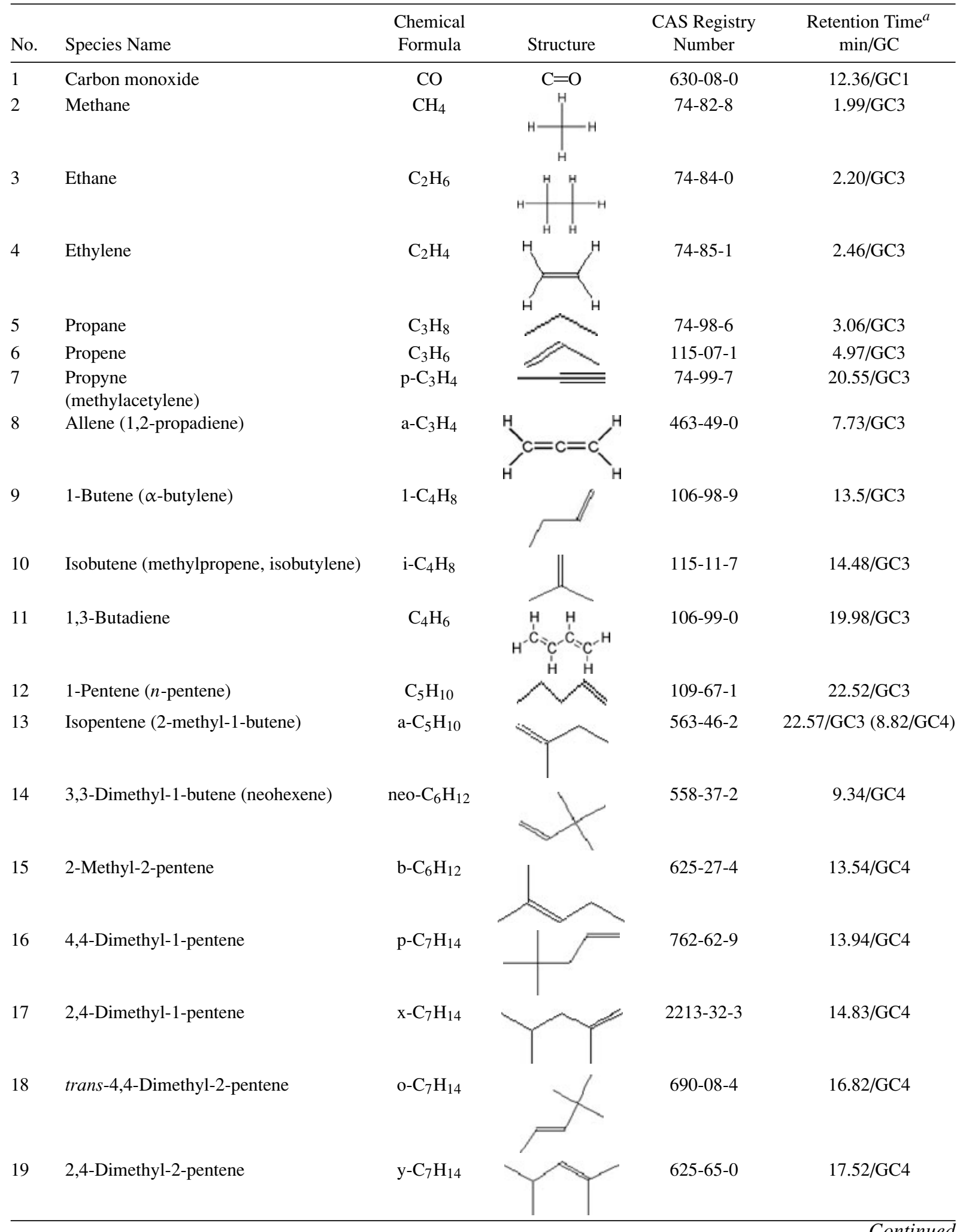


Table II Continued

\begin{tabular}{|c|c|c|c|c|c|}
\hline No. & Species Name & $\begin{array}{l}\text { Chemical } \\
\text { Formula }\end{array}$ & Structure & $\begin{array}{c}\text { CAS Registry } \\
\text { Number }\end{array}$ & $\begin{array}{c}\text { Retention Time } \\
\text { min/GC }\end{array}$ \\
\hline 20 & $2,2,4$-Trimethyl pentane (isooctane) & $\mathrm{i}-\mathrm{C}_{8} \mathrm{H}_{18}$ & & $540-84-1$ & $21.79 / \mathrm{GC} 4$ \\
\hline 21 & 2,4,4-Trimethyl-1-pentene & $\mathrm{j}-\mathrm{C}_{8} \mathrm{H}_{16}$ & & $107-39-1$ & $25.02 / \mathrm{GC} 4$ \\
\hline 22 & 2,4,4-Trimethyl-2-pentene & $\mathrm{i}-\mathrm{C}_{8} \mathrm{H}_{16}$ & & $107-40-4$ & 27.9/GC4 \\
\hline 23 & Acetaldehyde & $\mathrm{CH}_{3} \mathrm{CHO}$ & & $75-07-0$ & $6.87 / \mathrm{GC} 4$ \\
\hline 24 & Acetone (propanone) & $\mathrm{CH}_{3} \mathrm{COCH}_{3}$ & & $67-64-1$ & 16.64/GC2 (8.35/GC4) \\
\hline 25 & Propionaldehyde & $\mathrm{C}_{3} \mathrm{H}_{6} \mathrm{O} 1-2$ & & $123-38-6$ & $8.39 / \mathrm{GC} 4$ \\
\hline 26 & Isobutyraldehyde (2-methyl-1-propanal) & $\mathrm{i}-\mathrm{C}_{3} \mathrm{H}_{7} \mathrm{CHO}$ & & $78-84-2$ & (13.96/GC2) 10.28/GC4 \\
\hline 27 & Isobutylene oxide & $\mathrm{i}-\mathrm{C}_{4} \mathrm{H}_{8} \mathrm{O}$ & & $558-30-5$ & (13.99/GC2) 9.94/GC4 \\
\hline 28 & 2-Propen-1-ol (allyl alcohol) & $\mathrm{C}_{3} \mathrm{H}_{5} \mathrm{OH}$ & & $107-18-6$ & $\begin{array}{c}20.66 / \mathrm{GC} 2 \\
(10.01 / \mathrm{GC} 4)\end{array}$ \\
\hline 29 & Methacrolein & $\mathrm{i}-\mathrm{C}_{3} \mathrm{H}_{5} \mathrm{CHO}$ & & $78-85-3$ & $10.74 / \mathrm{GC} 4$ \\
\hline 30 & 2-Methyl-2-propen-1-ol (methallyl alcohol) & $\mathrm{i}-\mathrm{C}_{4} \mathrm{H}_{7} \mathrm{OH}$ & & $513-42-8$ & 22.62/GC2 (15.74/GC4) \\
\hline
\end{tabular}

${ }^{a}$ When species were detected on multiple GC systems, the measurements are reported for the GC/system that yielded better isolation and signal to noise. The second GC system is noted parenthetically.

$\left(\mathrm{C}_{3} \mathrm{H}_{5} \mathrm{OH}\right)$, and 2-methyl-2-propen-1-ol $\left(\mathrm{i}-\mathrm{C}_{4} \mathrm{H}_{7} \mathrm{OH}\right)$. Several features remain unidentified in the $\mathrm{GC} 2$ chromatograms and these are attributed to other oxygenated HCs.

Figure 3c presents a typical gas chromatogram from GC3, which was configured to monitor small hydrocarbons $\left(\mathrm{C}_{1}-\mathrm{C}_{5}\right)$. Eleven species were identified: methane $\left(\mathrm{CH}_{4}\right)$, ethane $\left(\mathrm{C}_{2} \mathrm{H}_{6}\right)$, ethene $\left(\mathrm{C}_{2} \mathrm{H}_{4}\right)$, propene $\left(\mathrm{C}_{3} \mathrm{H}_{6}\right)$, allene $\left(\mathrm{a}-\mathrm{C}_{3} \mathrm{H}_{4}\right)$, 1-butene $\left(1-\mathrm{C}_{4} \mathrm{H}_{8}\right)$, isobutene $\left(\mathrm{i}-\mathrm{C}_{4} \mathrm{H}_{8}\right)$, 1,3-butadiene $\left(\mathrm{C}_{4} \mathrm{H}_{6}\right)$, propyne $\left(\mathrm{p}-\mathrm{C}_{3} \mathrm{H}_{4}\right)$, 1-pentene $\left(\mathrm{C}_{5} \mathrm{H}_{10}\right)$, and 2-methyl-1-butene $\left(\mathrm{a}-\mathrm{C}_{5} \mathrm{H}_{10}\right)$. Note that a- $\mathrm{C}_{5} \mathrm{H}_{10}$ and $\mathrm{C}_{5} \mathrm{H}_{10}$ are not separated for this $\mathrm{GC}$ configuration. Consequently, the results are reported as the sum of these species. Several unidentified small hydrocarbons with relatively low concentrations were also present in the GC3 chromatograms. Note that acetylene $\left(\mathrm{C}_{2} \mathrm{H}_{2}\right)$ and formaldehyde $\left(\mathrm{CH}_{2} \mathrm{O}\right)$ were of particular interest in this work, and careful attention was paid to detecting these species. These compounds were not identified in any of the chromatograms, which indicate that the $\mathrm{C}_{2} \mathrm{H}_{2}$ and $\mathrm{CH}_{2} \mathrm{O}$ concentrations were below the $\mathrm{GC}$ detectivity limits for the GC detection used in this study. Similarly, acrolein $\left(\mathrm{CH}_{2} \mathrm{CHCHO}\right)$ was not observed.

A typical chromatogram for the large hydrocarbons $\left(\mathrm{C}_{5}-\mathrm{C}_{8}\right)$, isolated using $\mathrm{GC} 4$, is shown in Fig. 3d. The HC species identified included 2-methyl-1butene $\left(\mathrm{a}-\mathrm{C}_{5} \mathrm{H}_{10}\right), 2$-methyl-2-pentene $\left(\mathrm{b}-\mathrm{C}_{6} \mathrm{H}_{12}\right)$, 4,4-dimethyl-1-pentene $\quad\left(\mathrm{p}-\mathrm{C}_{7} \mathrm{H}_{14}\right), \quad$ 2,4-dimethyl1-pentene $\left(\mathrm{x}_{-}-\mathrm{C}_{7} \mathrm{H}_{14}\right)$, trans-4,4-dimethyl-2-pentene $\left(\mathrm{o}-\mathrm{C}_{7} \mathrm{H}_{14}\right)$, 2,4-dimethyl-2-pentene $\left(\mathrm{y}-\mathrm{C}_{7} \mathrm{H}_{14}\right)$, isooctane (i- $\left.\mathrm{C}_{8} \mathrm{H}_{18}\right), 2,4,4$-trimethyl-1-pentene $\left(\mathrm{j}-\mathrm{C}_{8} \mathrm{H}_{16}\right)$, and 2,4,4-trimethyl-2-pentene $\left(\mathrm{i}-\mathrm{C}_{8} \mathrm{H}_{16}\right)$. Some oxygenates were also separated, including acetaldehyde $\left(\mathrm{CH}_{3} \mathrm{CHO}\right)$, isobutyraldehyde $\left(\mathrm{i}-\mathrm{C}_{3} \mathrm{H}_{7} \mathrm{CHO}\right)$, methacrolein ( $\mathrm{i}-\mathrm{C}_{3} \mathrm{H}_{5} \mathrm{CHO}$ ), and 2-methyl-2-propen1-ol $\left(\mathrm{i}-\mathrm{C}_{4} \mathrm{H}_{7} \mathrm{OH}\right)$. When accurate concentration measurements of oxygenates were available from $\mathrm{GC} 2$, the GC4 oxygenate data were used for verification only. Note that large uncertainties were 
associated with the isooctane measurements at the $\phi=1.2$ conditions, which are attributed to effects of condensation. Consequently, $\mathrm{i}-\mathrm{C}_{8} \mathrm{H}_{18}$ data are presented for the $\phi=0.4$ condition only.

In order to quantify the species profiles throughout the ignition delay period, samples were acquired at discrete sampling intervals for two series of experiments targeted at fuel-lean and fuel-rich conditions. One gas sample was obtained for each RCF experiment. A summary of the experimental conditions are presented in Tables III and IV for the $\phi=0.4$ and $\phi=1.2$ mixtures, respectively. As seen in the tables, due to slight variations in the end of compression conditions, the ignition delay times varied slightly for each experiment. To compensate for these variations, the sampling time was normalized for each experiment using the ignition delay time. The start time of gas sampling, shown in Fig. 2 as $t_{1}$, was defined as the time interval between the end of compression and the start of gas sampling. The end time of gas sampling, shown in Fig. 2 as $t_{2}$, was defined as the time interval between the end of compression and the end of gas sampling. The normalized sampling time, $t_{\text {norm }}$, was then defined as

$$
t_{\text {norm }}=\frac{\left(t_{1}+t_{2}\right)}{2 \cdot \tau_{\text {ign }}}
$$

where $\tau_{\text {ign }}$ is the ignition delay time.

For the lean $\phi=0.4$ mixture, the reactant mixture composition was fixed at $\chi_{\mathrm{i}-\mathrm{C}_{8} \mathrm{H}_{18}}=0.53 \%$, $\chi_{\mathrm{Ar}}=9.8 \%, \chi_{\mathrm{O}_{2}}=16.6 \%$, and $\chi_{\mathrm{N}_{2}}=73.1 \%$ (mole fraction basis), and the target pressure and temperature were $P=5.2$ atm and $T=1000 \mathrm{~K}$. The actual experimental pressures and temperatures were in the range of 5.2-5.5 atm and 993-1010 K, respectively. For the rich $\phi=1.2$ mixture, the reactant mixture composition was fixed at $\chi_{\mathrm{i}-\mathrm{C}_{8} \mathrm{H}_{18}}=1.58 \%, \chi_{\mathrm{O}_{2}}=16.4 \%, \chi_{\mathrm{N}_{2}}=40.7 \%$, $\chi_{\mathrm{Ar}}=41.3 \%$ (mole fraction basis), and the target pressure and temperature were $P=4.8$ atm and $T=975 \mathrm{~K}$. The actual experimental pressures and temperatures were in the range of 4.7-4.8 atm and 972-978 K, respectively. The experimental results for

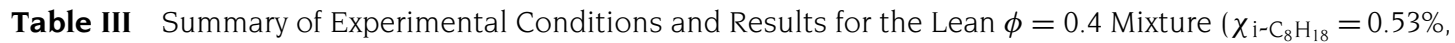
$\chi_{\mathrm{Ar}}=9.8 \%, \chi_{\mathrm{O}_{2}}=16.6 \%, \chi_{\mathrm{N}_{2}}=73.1 \%$, Mole Fraction Basis)

\begin{tabular}{lccccc}
\hline$t_{\text {norm }}$ & $P_{\text {eff }}(\mathrm{atm})$ & $T_{\text {eff }}(\mathrm{K})$ & $\tau_{\text {ign }}(\mathrm{ms})$ & $t_{1}(\mathrm{~ms})$ & $t_{2}(\mathrm{~ms})$ \\
\hline 0.10 & 5.3 & 997 & 21.1 & 1.18 & 3.23 \\
0.15 & 5.3 & 997 & 21.0 & 2.10 & 4.20 \\
0.20 & 5.2 & 993 & 22.8 & 3.40 & 5.70 \\
0.25 & 5.3 & 997 & 21.1 & 4.22 & 6.33 \\
0.27 & 5.2 & 994 & 21.6 & 4.71 & 6.91 \\
0.36 & 5.2 & 1002 & 19.1 & 5.84 & 7.85 \\
0.48 & 5.3 & 1003 & 19.6 & 8.23 & 10.39 \\
0.51 & 5.4 & 1002 & 18.7 & 8.53 & 10.58 \\
0.61 & 5.3 & 1004 & 18.6 & 10.23 & 12.28 \\
0.66 & 5.4 & 1001 & 17.9 & 10.56 & 12.89 \\
0.66 & 5.3 & 1002 & 20.4 & 14.16 & 14.48 \\
0.79 & 5.3 & 999 & 19.4 & 16.00 & 16.30 \\
0.85 & 5.3 & 1001 & 20.0 & 16.61 & 18.00 \\
0.86 & 5.3 & 1010 & 15.5 & 11.99 & 18.59 \\
0.86 & 5.5 & 1005 & 17.4 & 15.16 & 14.20 \\
0.93 & 5.4 & & 17.26 \\
\hline
\end{tabular}

Table IV Summary of Experimental Conditions and Results for the Rich $\phi=1.2$ Mixture $\left(\chi_{\mathrm{i}-\mathrm{C}_{8} \mathrm{H}_{18}}=1.58 \%\right.$, $\chi \mathrm{O}_{2}=16.4 \%, \chi_{\mathrm{N}_{2}}=40.7 \%, \chi \mathrm{Ar}=41.3 \%$, Mole Fraction Basis)

\begin{tabular}{lcccrr}
\hline$t_{\text {norm }}$ & $P_{\text {eff }}(\mathrm{atm})$ & $T_{\text {eff }}(\mathrm{K})$ & $\tau_{\text {ign }}(\mathrm{ms})$ & $t_{1}(\mathrm{~ms})$ & $t_{2}(\mathrm{~ms})$ \\
\hline 0.15 & 4.7 & 973 & 15.1 & 1.19 & 3.17 \\
0.15 & 4.7 & 972 & 15.0 & 0.99 & 3.45 \\
0.42 & 4.8 & 975 & 13.6 & 4.60 & 6.70 \\
0.54 & 4.8 & 978 & 13.5 & 6.26 & 8.19 \\
0.64 & 4.8 & 974 & 14.4 & 8.28 & 10.17 \\
0.75 & 4.8 & 977 & 14.2 & 9.66 & 11.54 \\
0.84 & 4.8 & 975 & 14.8 & 11.14 & 13.56 \\
\hline
\end{tabular}


ignition delay time $\tau_{\text {ign }}$, the start time of gas sampling $t_{1}$, the end time of gas sampling $t_{2}$, and the normalized sampling time $t_{\text {norm }}$ are included in Tables III and IV.

Experimental results for the measurements of the intermediate species mole fractions for the two target mixtures and conditions are presented in Fig. 4.
The species in Fig. 4 are presented in the order listed in Table II. Experiments were conducted at the lean mixture target conditions to evaluate the repeatability of the measurements for $t_{\text {norm }}=0.66$ and $t_{\text {norm }}=0.85$. For both the rich and lean cases, $\mathrm{CO}, \mathrm{CH}_{4}, \mathrm{C}_{3} \mathrm{H}_{6}$, and $\mathrm{i}-\mathrm{C}_{4} \mathrm{H}_{8}$ were produced in the largest quantities,
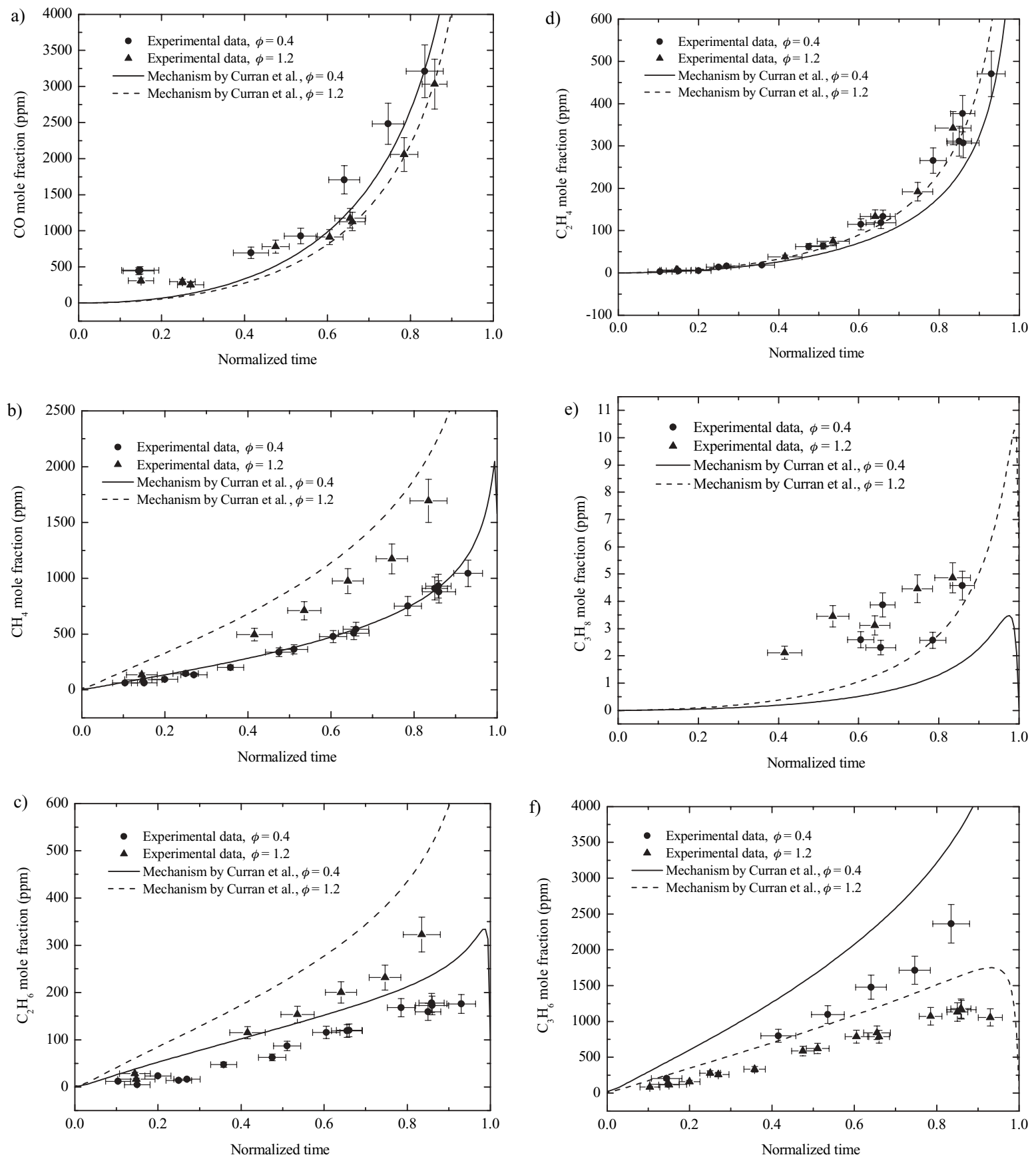

Figure 4 Experimental and modeling results for $\mathrm{HC}$ intermediate gas species during isooctane ignition for the target conditions and mixtures of $\phi=0.4\left(\chi_{\mathrm{i}}-\mathrm{C}_{8} \mathrm{H}_{18}=0.53 \%, \chi_{\mathrm{Ar}}=9.8 \%, \chi_{\mathrm{O}_{2}}=16.6 \%, \chi_{\mathrm{N}_{2}}=73.1 \%\right), P=5.2 \mathrm{~atm}, T=1000 \mathrm{~K}$ and $\phi=1.2\left(\chi_{\mathrm{i}^{-}}\right.$ $\left.\mathrm{C}_{8} \mathrm{H}_{18}=1.58 \%, \chi_{\mathrm{Ar}}=41.3 \%, \chi_{\mathrm{O}_{2}}=16.4 \%, \chi_{\mathrm{N}_{2}}=40.7 \%\right), P=4.8 \mathrm{~atm}, T=975 \mathrm{~K}$. The error bars represent the experimental uncertainties. The time domain has been normalized from $t=0$ (end of compression) to $t=1$ (time of ignition). See text for details. (Continued) 

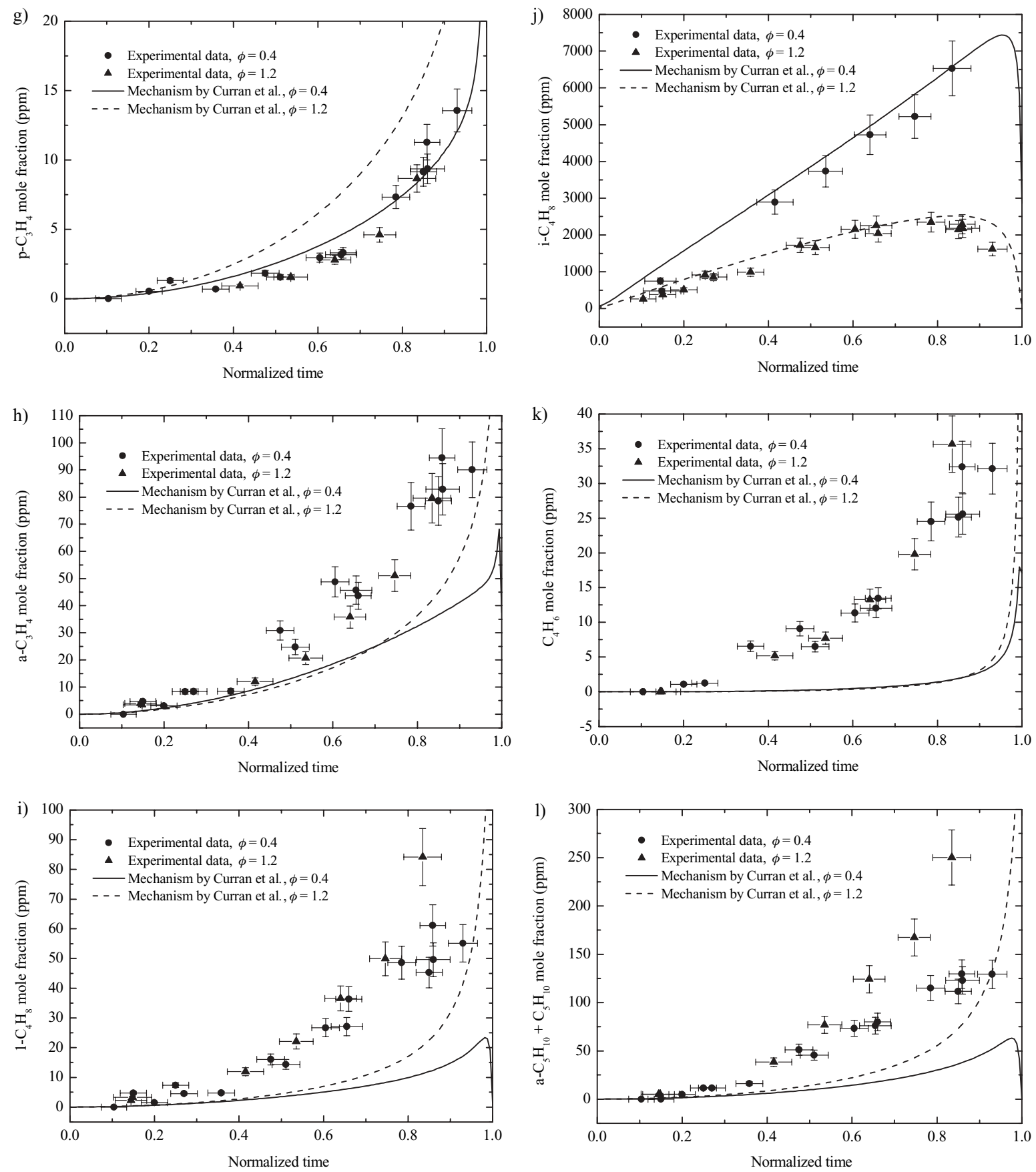

Figure 4 (Continued)

with peak mole fractions over 1000 ppm (Figs. 4a, $4 \mathrm{~b}, 4 \mathrm{f}$, and $4 \mathrm{j}$ ). The four isomers of $\mathrm{C}_{7} \mathrm{H}_{14}, \mathrm{x}-\mathrm{C}_{7} \mathrm{H}_{14}$, o- $\mathrm{C}_{7} \mathrm{H}_{14}, \mathrm{y}-\mathrm{C}_{7} \mathrm{H}_{14}$, and $\mathrm{p}-\mathrm{C}_{7} \mathrm{H}_{14}$, were observed at levels on the order of 100 ppm (see Figs. 4o-4r) for both conditions. Several species, including $\mathrm{p}-\mathrm{C}_{3} \mathrm{H}_{4}$, b$\mathrm{C}_{6} \mathrm{H}_{12}$, neo- $\mathrm{C}_{6} \mathrm{H}_{12}, \mathrm{i}-\mathrm{C}_{8} \mathrm{H}_{16}, \mathrm{j}-\mathrm{C}_{8} \mathrm{H}_{16}, \mathrm{C}_{3} \mathrm{H}_{5} \mathrm{OH}$, and i- $\mathrm{C}_{4} \mathrm{H}_{7} \mathrm{OH}$ were observed at trace amounts, where the maximum mole fractions were less than $20 \mathrm{ppm}$. The remaining species data presented in Fig. 4 were observed at mole fractions on the order of 100 ppm. Many of the species did not indicate sensitivity to the two equivalence ratios and conditions considered (e.g., $\mathrm{CO}, \mathrm{C}_{2} \mathrm{H}_{4}, \mathrm{C}_{3} \mathrm{H}_{8}, \mathrm{p}-\mathrm{C}_{3} \mathrm{H}_{4}, \mathrm{a}-\mathrm{C}_{3} \mathrm{H}_{4}$, $1-\mathrm{C}_{4} \mathrm{H}_{8}, \mathrm{C}_{4} \mathrm{H}_{6}, \mathrm{CH}_{3} \mathrm{CHO}, \mathrm{CH}_{3} \mathrm{COCH}_{3}, \mathrm{C}_{3} \mathrm{H}_{6} \mathrm{O} 1-2$, $\mathrm{i}-\mathrm{C}_{3} \mathrm{H}_{7} \mathrm{CHO}, \mathrm{i}-\mathrm{C}_{3} \mathrm{H}_{5} \mathrm{CHO}$, and $\left.\mathrm{i}-\mathrm{C}_{4} \mathrm{H}_{7} \mathrm{OH}\right)$. However, a few compounds demonstrated significant sensitivity to the change in conditions (e.g., $\mathrm{i}-\mathrm{C}_{4} \mathrm{H}_{8}$ and the four isomers of $\left.\mathrm{C}_{7} \mathrm{H}_{14}\right)$. The mechanisms for the formation 

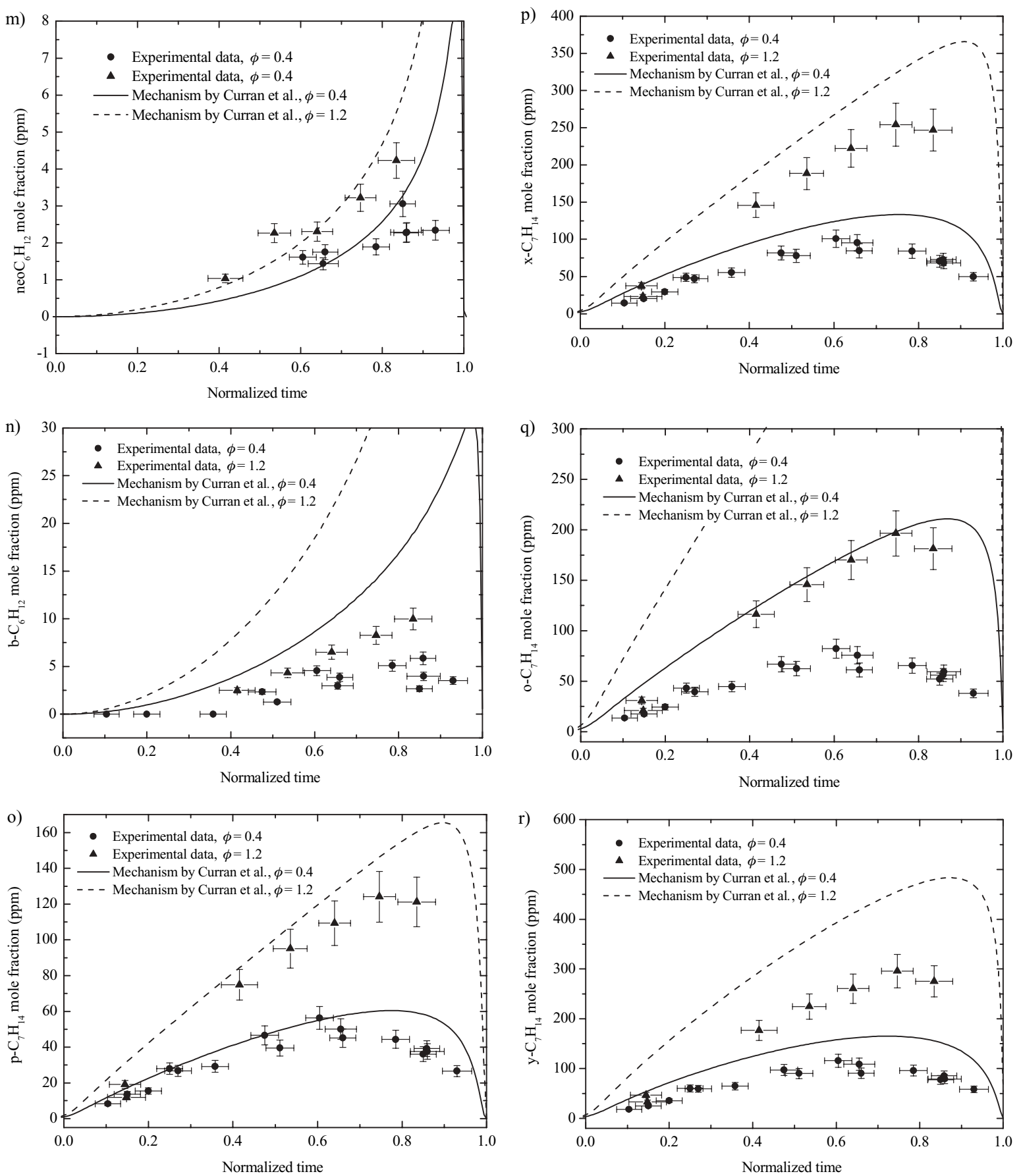

Figure 4 (Continued)

and removal the individual species are discussed below.

\section{EXPERIMENTAL UNCERTAINTIES}

Experimental uncertainties exist in determining the species mole fractions and the normalized time. In determining the species mole fractions, the largest uncertainty is from the calculation of the dilution ratio, $\zeta$. The dilution ratio is primarily affected by the uncertainty in the temperature of the dead volume (estimated to be $\pm 50 \mathrm{~K}$ ) and the estimated size of the dead volume. These uncertainties contribute a maximum error of $\pm 10 \%$ in the determination of the intermediate species mole fractions. A second source 

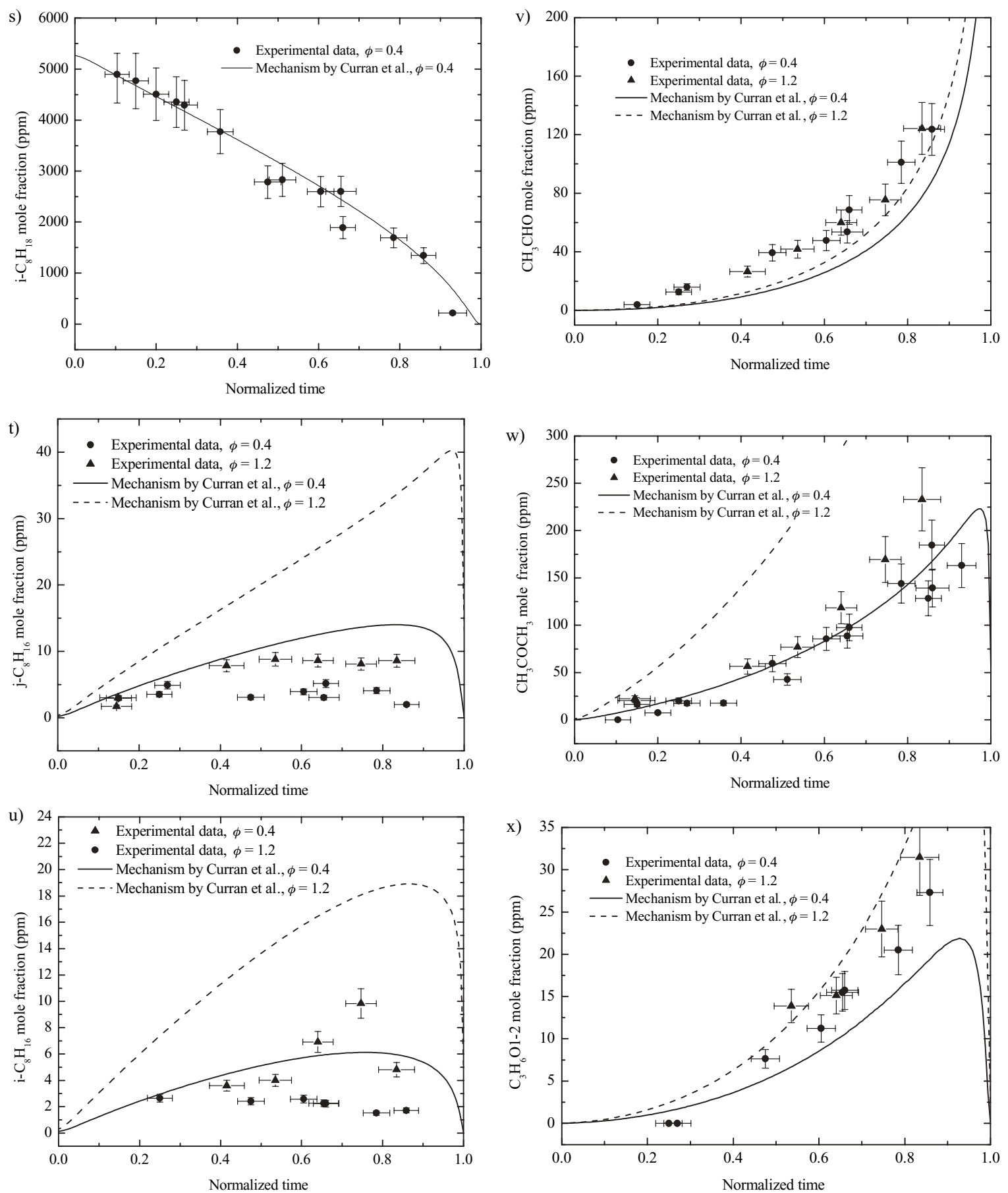

Figure 4 (Continued)

of uncertainty in the species measurements is due to the accuracy of the GC calibrations. Based on the calibration results, an uncertainty of $\pm 4 \%$ is assigned to the permanent gases and the small and large hydrocarbons. An uncertainty of $\pm 8 \%$ is assigned to the oxygenates measured in GC2. The third uncertainty in the species measurements is due to variation in the ex- perimental conditions and is estimated as a maximum of $\pm 5 \%$. Combining the sources of uncertainty using a square root of the sum-of-the-squares approach yields an overall uncertainty in the species mole fraction of $\pm 12 \%$ for the permanent gases and small and large hydrocarbons and $\pm 14 \%$ for the oxygenates, except isobutylene oxide $\left(\mathrm{i}-\mathrm{C}_{4} \mathrm{H}_{8} \mathrm{O}\right)$. Because the retention 

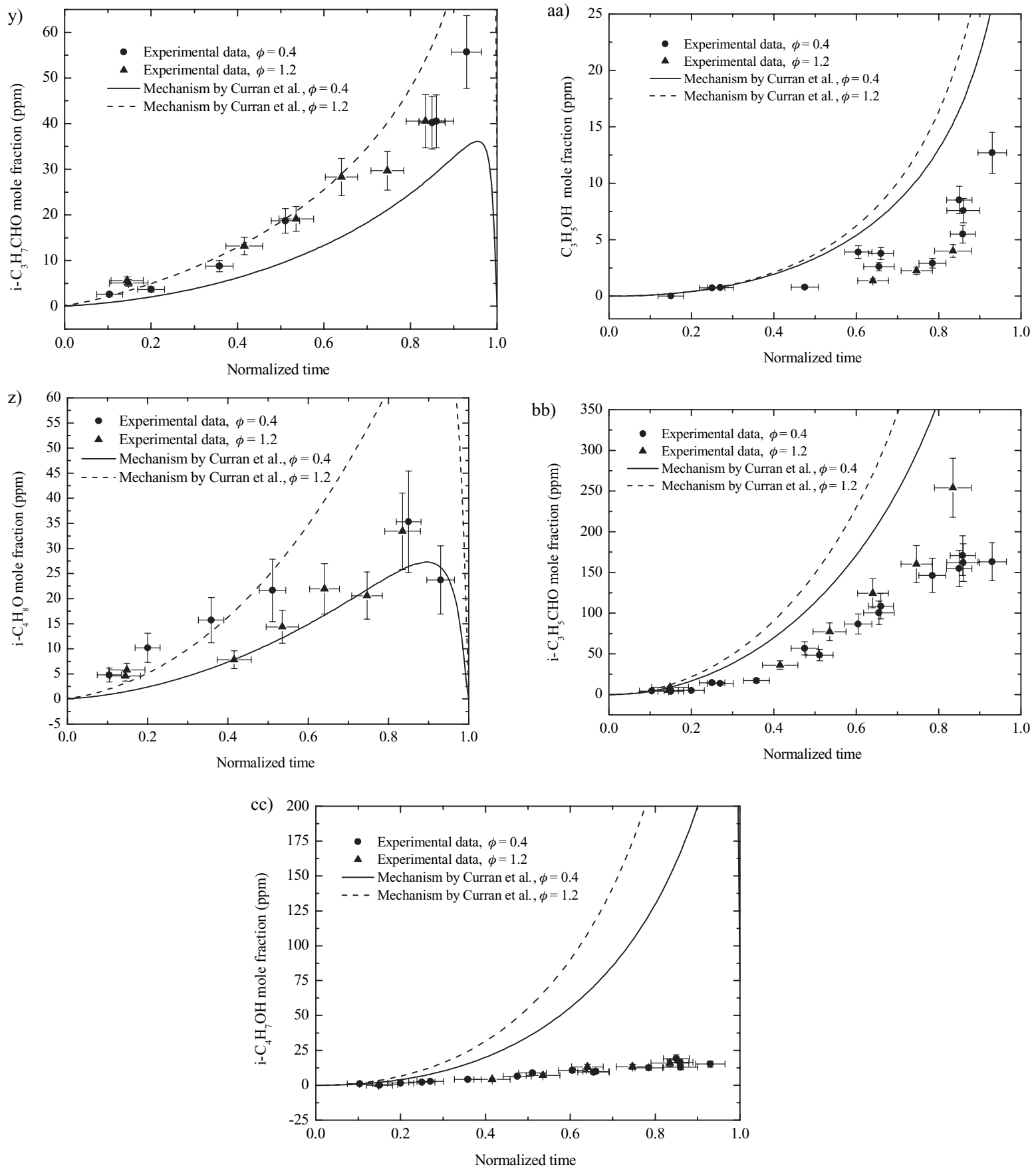

Figure 4 (Continued)

time of $\mathrm{i}-\mathrm{C}_{4} \mathrm{H}_{8} \mathrm{O}$ is very close to that of $\mathrm{i}-\mathrm{C}_{3} \mathrm{H}_{7} \mathrm{CHO}$ in $\mathrm{GC} 2$ and $\mathrm{C}_{3} \mathrm{H}_{5} \mathrm{OH}$ in $\mathrm{GC} 4$ (see Table II), $\mathrm{i}-\mathrm{C}_{4} \mathrm{H}_{8} \mathrm{O}$ is assigned an uncertainty of $\pm 28 \%$.

The uncertainties in time are due to variation in the experimental conditions, assigned a maximum uncertainty of \pm 0.018 in normalized time, and the effects of finite sampling time. Since the sampling process spans $2.1 \mathrm{~ms}$, the measured species mole fractions are necessarily time-averaged. This effect on the normalized time is represented as an uncertainty of half the sampling interval or approximately $1 \mathrm{~ms}$. Combining the sources of uncertainty using a square root of the sum-of-the-squares approach yields an overall uncertainty of \pm 0.03 in normalized time for the lean experiments $(\phi=0.4)$ and an overall uncertainty of \pm 0.04 in normalized time for the rich experiments $(\phi=1.2)$. 
The overall uncertainties in the normalized time and species measurements are presented as the error bars in Fig. 4.

\section{DISCUSSION}

\section{Model Simulations}

In order to better understand the reaction chemistry leading to the species profiles observed, CHEMKIN modeling of the RCF experiments was conducted using the detailed reaction mechanism of Curran et al. [11]. Several isooctane combustion mechanisms were considered. The mechanism by Curran et al. [11] was selected because of the high level of agreement that was achieved previously using this mechanism in isooctane ignition studies of $\mathrm{OH}$ time histories [15]. For the modeling studies, the AURORA ${ }^{\mathrm{TM}} / \mathrm{CHEMKIN}^{\mathrm{TM}}$ suite of programs [31] was used. In the simulation, a spatially homogeneous time-varying system was assumed, which included the last $10 \mathrm{~ms}$ of the compression process and the ignition process of the core gas mixture. The volume time history used in the model was obtained in the following manner. The pressure time history of a typical experiment was divided into two time intervals: compression and postcompression. During compression, changes in pressure and temperature due to chemical reaction are small (although some reaction can occur in the final stages of compression). Isentropic compression was assumed, and a polynomial fit was applied to the experimental pressure trace to calculate the volume change during compression. After compression, the test gas in the core region undergoes a slight expansion (due to heat losses to the chamber walls). In order to obtain the expansion rate of the core gases in the test section (or in other words estimate the effects of the heat losses on the core region of the test gases), inert gas experiments were conducted at comparable experimental conditions to the isooctane ignition studies. Typical results are shown in Fig. 5. The pressure trace of the inert gas experiments after compression was then used to calculate the volume expansion of the core gas, again assuming an isentropic process. The compression and expansion processes were treated as adiabatic, with constant internal energy.

The modeling results are presented in Fig. 4, where the solid lines represent the $\phi=0.4$ simulation and the dashed lines represent the $\phi=1.2$ simulation. In general, there is excellent agreement between the model results and the experimental data for even trace species. The few exceptions include underpredicting $\mathrm{C}_{4} \mathrm{H}_{6}$ and overpredicting b- $\mathrm{C}_{6} \mathrm{H}_{12}, o-\mathrm{C}_{7} \mathrm{H}_{14}, \mathrm{j}-\mathrm{C}_{6} \mathrm{H}_{16}, \mathrm{i}-\mathrm{C}_{6} \mathrm{H}_{16}$, and $\mathrm{i}-\mathrm{C}_{4} \mathrm{H}_{7} \mathrm{OH}$. All of these species were measured at low levels $(<40 \mathrm{ppm})$, except $\mathrm{o}-\mathrm{C}_{7} \mathrm{H}_{14}$, which was

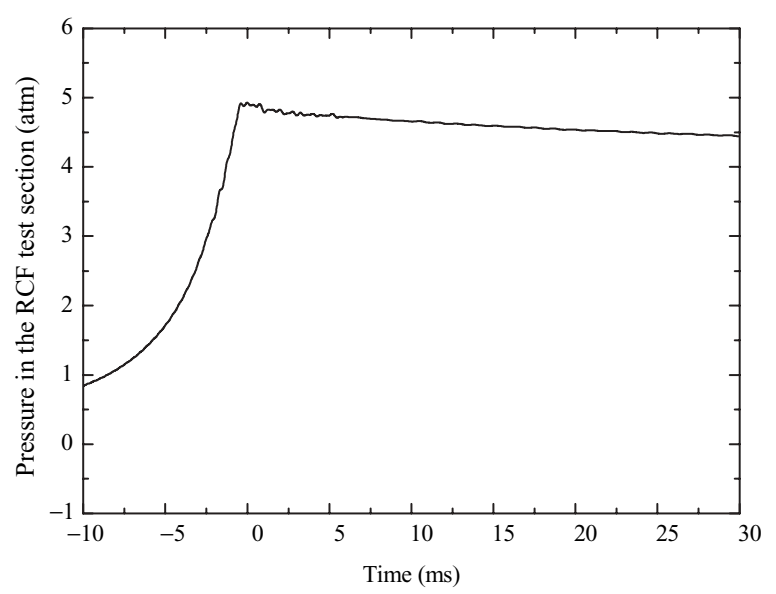

Figure 5 Typical pressure time history in the test section during an inert gas experiment (used to estimate the effects of heat losses in the test section) for conditions of $P_{\text {eff }}=4.8 \mathrm{~atm}$, $100 \% \mathrm{~N}_{2}$.

measured at levels between 10 and $200 \mathrm{ppm}$. Based on the high level of agreement, the mechanism by Curran et al. [11] is considered suitable for interpretation of the measurements in terms of the detailed isooctane ignition chemistry. In the following sections, the pathways for formation and destruction of the various hydrocarbons and oxygenates are discussed in detail.

\section{Hydrocarbons}

The modeling study by Curran et al. [11] proposed that the overall reaction scheme of isooctane oxidation at intermediate temperatures is via $\mathrm{H}$-atom abstraction from i- $\mathrm{C}_{8} \mathrm{H}_{18}$ to form $\mathrm{x}-\mathrm{C}_{8} \mathrm{H}_{17}$ isomers, which then undergo $\beta$-scission to form olefin species and alkyl radicals. The current results support that scheme where after removal of an $\mathrm{H}$ atom, the isooctyl radicals undergo $\beta$-scission to form primarily i- $\mathrm{C}_{4} \mathrm{H}_{8}$ and $\mathrm{i}-\mathrm{C}_{4} \mathrm{H}_{9}$. The $\mathrm{i}-\mathrm{C}_{4} \mathrm{H}_{9}$ radicals further undergo reaction to yield $\mathrm{C}_{3} \mathrm{H}_{6}$ and methyl $\left(\mathrm{CH}_{3}\right)$ radicals. As shown in Figs. $4 \mathrm{f}$ and $4 \mathrm{j}, \mathrm{i}-\mathrm{C}_{4} \mathrm{H}_{8}$ and $\mathrm{C}_{3} \mathrm{H}_{6}$ were the major olefin products identified by the experimental results, and the model results are in very good quantitative agreement with the experimental data throughout the time histories.

We have presented a reaction path diagram based on rate of production of analysis for isooctane ignition at similar experimental conditions in a previous work [15] using the mechanism by Curran et al. [11]. The major species observed in this study (e.g., $\mathrm{i}-\mathrm{C}_{4} \mathrm{H}_{8}, \mathrm{C}_{3} \mathrm{H}_{6}$ ) were produced and consumed via the same reaction sequences as shown in [15]. In the following paragraphs, the reaction sources and sinks are expanded and described in detail for the species observed in this study.

Significant amounts of $\mathrm{C} 7$ olefins were observed in the experimental measurements and simulation 
predictions, including 4,4-dimethyl-1-pentene (p- $\left.\mathrm{C}_{7} \mathrm{H}_{14}\right), 2$,4-dimethyl-1-pentene $\left(\mathrm{x}-\mathrm{C}_{7} \mathrm{H}_{14}\right)$, trans4,4-dimethyl-2-pentene (o- $\left.\mathrm{C}_{7} \mathrm{H}_{14}\right)$, and 2,4-dimethyl2-pentene $\left(\mathrm{y}-\mathrm{C}_{7} \mathrm{H}_{14}\right)$. Based on the mechanism by Curran et al. [11], the $\mathrm{C} 7$ olefins are formed via the following reactions by $\beta$-scission of isooctyl radicals ((R1)-(R4)):

$$
\begin{aligned}
& \text { b- } \dot{\mathrm{C}}_{8} \mathrm{H}_{17} \rightarrow \text { o- } \mathrm{C}_{7} \mathrm{H}_{14}+\dot{\mathrm{C}} \mathrm{H}_{3} \\
& \text { b- } \dot{\mathrm{C}}_{8} \mathrm{H}_{17} \rightarrow \mathrm{y}-\mathrm{C}_{7} \mathrm{H}_{14}+\dot{\mathrm{C}} \mathrm{H}_{3} \\
& \text { a- } \dot{\mathrm{C}}_{8} \mathrm{H}_{17} \rightarrow \mathrm{x}-\mathrm{C}_{7} \mathrm{H}_{14}+\dot{\mathrm{C}} \mathrm{H}_{3} \\
& \text { d- } \dot{\mathrm{C}}_{8} \mathrm{H}_{17} \rightarrow \mathrm{p}-\mathrm{C}_{7} \mathrm{H}_{14}+\dot{\mathrm{C}} \mathrm{H}_{3}
\end{aligned}
$$

In (R1)-(R4), the isooctyl radicals differ by the location of the $\mathrm{H}$-atom removed. Here, we are following the notation used by Curran et al. [11]:

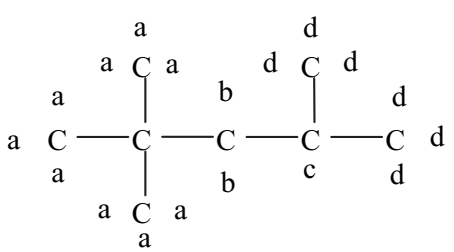

The $\mathrm{p}-\mathrm{C}_{7} \mathrm{H}_{14}, \mathrm{x}-\mathrm{C}_{7} \mathrm{H}_{14}$, and $\mathrm{y}-\mathrm{C}_{7} \mathrm{H}_{14}$ isomers are well predicted by the simulations (see Figs. 4o, 4p, and 4r), whereas, as noted earlier, $\mathrm{o}-\mathrm{C}_{7} \mathrm{H}_{14}$ is overpredicted by more than a factor of 2 (see Fig. 4q).

Methane is produced in large quantities via the reactions of methyl with hydroperoxyl $\left(\mathrm{HO}_{2}\right)$ and with formaldehyde $\left(\mathrm{CH}_{2} \mathrm{O}\right)$ via

$$
\begin{gathered}
\mathrm{CH}_{3}+\mathrm{HO}_{2} \rightarrow \mathrm{CH}_{4}+\mathrm{O}_{2} \\
\mathrm{CH}_{3}+\mathrm{CH}_{2} \mathrm{O} \rightarrow \mathrm{CH}_{4}+\mathrm{HCO}
\end{gathered}
$$

A negligible amount of $\mathrm{CH}_{4}$ is produced from the reaction of methyl with isooctane for the conditions studied. The Curran mechanism showed exceptional performance in reproducing the experimental results for $\mathrm{CH}_{4}$ at fuel-lean conditions, and very good performance for predicting $\mathrm{CH}_{4}$ at the fuel-rich data (see Fig. 4b).

$\mathrm{C}_{2} \mathrm{H}_{6}$ is produced by the recombination of methyl radicals

$$
\mathrm{CH}_{3}+\mathrm{CH}_{3} \rightarrow \mathrm{C}_{2} \mathrm{H}_{6}
$$

whereas $\mathrm{C}_{2} \mathrm{H}_{4}$ is formed primarily by

$$
\mathrm{C}_{2} \mathrm{H}_{5}+\mathrm{O}_{2} \rightarrow \mathrm{C}_{2} \mathrm{H}_{4}+\mathrm{HO}_{2}
$$

with additional contributions from the reactions

$$
\begin{aligned}
n-\mathrm{C}_{3} \mathrm{H}_{7} & \rightarrow \mathrm{CH}_{3}+\mathrm{C}_{2} \mathrm{H}_{4} \\
\mathrm{C}_{3} \mathrm{H}_{6}+\mathrm{H} & \rightarrow \mathrm{C}_{2} \mathrm{H}_{4}+\mathrm{CH}_{3}
\end{aligned}
$$

$\mathrm{C}_{2} \mathrm{H}_{5}$ that reacts via (R8) is created primarily by the reaction of $\mathrm{C}_{2} \mathrm{H}_{6}$ with $\mathrm{OH}$ to form $\mathrm{C}_{2} \mathrm{H}_{5}$ and $\mathrm{H}_{2} \mathrm{O}$.

Allene $\left(\mathrm{a}-\mathrm{C}_{3} \mathrm{H}_{4}\right)$ is created by reaction of isobutene (i- $\mathrm{C}_{4} \mathrm{H}_{7}$ ) with $\mathrm{O}_{2}$ and the $\beta$-scission of $\mathrm{i}-\mathrm{C}_{4} \mathrm{H}_{7}$ :

$$
\begin{aligned}
\mathrm{i}-\mathrm{C}_{4} \mathrm{H}_{7}+\mathrm{O}_{2} & \rightarrow \mathrm{a}-\mathrm{C}_{3} \mathrm{H}_{4}+\mathrm{CH}_{2} \mathrm{O}+\mathrm{OH}(\mathrm{R} 11) \\
\mathrm{i}-\mathrm{C}_{4} \mathrm{H}_{7} & \rightarrow \mathrm{a}-\mathrm{C}_{3} \mathrm{H}_{4}+\mathrm{CH}_{3} \quad(\mathrm{R} 12)
\end{aligned}
$$

$\mathrm{i}-\mathrm{C}_{4} \mathrm{H}_{7}$ is produced primarily by $\mathrm{H}$-atom abstraction by $\mathrm{OH}$ from $\mathrm{i}-\mathrm{C}_{4} \mathrm{H}_{8}$, and it is consumed primarily by reaction with $\mathrm{HO}_{2}$. As a consequence, the $\mathrm{i}-\mathrm{C}_{4} \mathrm{H}_{7}$ profile is sensitive to $\mathrm{H}_{2} / \mathrm{O}_{2}$ reaction kinetics, as discussed further below.

2-Methyl-1-butene $\left(\mathrm{a}-\mathrm{C}_{5} \mathrm{H}_{10}\right)$ was another major intermediate species formed during isooctane oxidation via the combination of $\mathrm{i}-\mathrm{C}_{4} \mathrm{H}_{7}$ with $\mathrm{CH}_{3}$ :

$$
\mathrm{i}-\mathrm{C}_{4} \mathrm{H}_{7}+\mathrm{CH}_{3} \rightarrow \mathrm{a}-\mathrm{C}_{5} \mathrm{H}_{10}
$$

1-Butene $\left(1-\mathrm{C}_{4} \mathrm{H}_{8}\right)$ was formed in appreciable concentration and predicted to be generated via the reaction of the allyl radical $\left(\mathrm{a}-\mathrm{C}_{3} \mathrm{H}_{5}\right)$ with methyl:

$$
\mathrm{a}-\mathrm{C}_{3} \mathrm{H}_{5}+\mathrm{CH}_{3} \rightarrow 1-\mathrm{C}_{4} \mathrm{H}_{8}
$$

Both $1-\mathrm{C}_{4} \mathrm{H}_{8}$ and $\mathrm{a}-\mathrm{C}_{5} \mathrm{H}_{10}$ were underpredicted by the simulation for both the lean and rich conditions (see Figs. $4 \mathrm{i}$ and $4 \mathrm{l}$ ). This result for $\mathrm{a}-\mathrm{C}_{5} \mathrm{H}_{10}$ is consistent with the study by Chen et al. [10], where the authors also found that $\mathrm{a}-\mathrm{C}_{5} \mathrm{H}_{10}$ was predicted to form via (R13), and the model results showed consistently lower values than the experimental data. Chen et al. [10] proposed that "there may be an alternative route to its formation" that is not captured in the mechanism developed by Curran et al. [11]. The results of the current work support the hypothesis that other formation pathways may be active.

Propyne $\left(\mathrm{p}-\mathrm{C}_{3} \mathrm{H}_{4}\right)$ is generated in very small quantities (see Fig. 4g), mainly via

$$
\mathrm{t}-\mathrm{C}_{3} \mathrm{H}_{5} \rightarrow \mathrm{p}-\mathrm{C}_{3} \mathrm{H}_{4}+\mathrm{H}
$$

and

$$
\mathrm{i}-\mathrm{C}_{4} \mathrm{H}_{7}-i 1 \rightarrow \mathrm{p}-\mathrm{C}_{3} \mathrm{H}_{4}+\mathrm{CH}_{3}
$$

and is well predicted by the model simulations. 
1,3-Butadiene $\left(\mathrm{C}_{4} \mathrm{H}_{6}\right)$ was another hydrocarbon formed at a relatively low level, which was predicted to be generated via $\beta$-scission of 1-penten-3-yl radical $\left(\mathrm{C}_{5} \mathrm{H}_{9}\right)$

$$
\mathrm{C}_{5} \mathrm{H}_{9} \rightarrow \mathrm{C}_{4} \mathrm{H}_{6}+\mathrm{CH}_{3}
$$

and the reaction of 1-buten-3-yl radical $\left(\mathrm{C}_{4} \mathrm{H}_{7}\right)$ with $\mathrm{O}_{2}$

$$
\mathrm{C}_{4} \mathrm{H}_{7}+\mathrm{O}_{2} \rightarrow \mathrm{C}_{4} \mathrm{H}_{6}+\mathrm{HO}_{2}
$$

The Curran mechanism significantly underpredicts the formation of $\mathrm{C}_{4} \mathrm{H}_{6}$ (see Fig. 4k), which supports the hypothesis that certain reaction sequences may be missing for these $\mathrm{C} 4$ species, as indicated by the $a-\mathrm{C}_{5} \mathrm{H}_{10}$ data.

2-Methyl-2-pentene $\left(b-\mathrm{C}_{6} \mathrm{H}_{12}\right)$ is formed primarily via $\beta$-scission of the $\mathrm{o}_{-} \mathrm{C}_{7} \mathrm{H}_{15}$ radical:

$$
\text { o- } \mathrm{C}_{7} \mathrm{H}_{15} \rightarrow \text { b- } \mathrm{C}_{6} \mathrm{H}_{12}+\mathrm{CH}_{3}
$$

and is significantly overpredicted by the simulation results (see Fig. 4n). This result is consistent with the model predictions for $0-\mathrm{C}_{7} \mathrm{H}_{14}$, which are approximately a factor of 2 higher than the experimental data, since $\mathrm{o}-\mathrm{C}_{7} \mathrm{H}_{15}$ is produced by the addition of $\mathrm{H}$ to o- $\mathrm{C}_{7} \mathrm{H}_{14}$. In other words, because o- $\mathrm{C}_{7} \mathrm{H}_{14}$ is overpredicted, so are o- $\mathrm{C}_{7} \mathrm{H}_{15}$ and $\mathrm{b}-\mathrm{C}_{6} \mathrm{H}_{12}$.

2,4,4-Trimethyl-1-pentene $\left(\mathrm{j}-\mathrm{C}_{8} \mathrm{H}_{16}\right)$ and 2,4,4trimethyl-2-pentene $\left(\mathrm{i}-\mathrm{C}_{8} \mathrm{H}_{16}\right)$ are formed via

$$
\begin{aligned}
\text { b- } \mathrm{C}_{8} \mathrm{H}_{17} & \rightarrow \mathrm{i}-\mathrm{C}_{8} \mathrm{H}_{16}+\mathrm{H} \\
\text { b- } \mathrm{C}_{8} \mathrm{H}_{16} \mathrm{OOH}-c & \rightarrow \mathrm{i}-\mathrm{C}_{8} \mathrm{H}_{16}+\mathrm{HO}_{2} \\
\text { d- } \mathrm{C}_{8} \mathrm{H}_{17} & \rightarrow \text { j- } \mathrm{C}_{8} \mathrm{H}_{16}+\mathrm{H}
\end{aligned}
$$

The experimental and model results are in reasonable agreement for the $\phi=0.4$ conditions, but the model overpredicts $\mathrm{j}-\mathrm{C}_{8} \mathrm{H}_{16}$ and $\mathrm{i}-\mathrm{C}_{8} \mathrm{H}_{16}$ at the $\phi=1.2$ conditions.

Note that individual $\mathrm{R}+\mathrm{O}_{2}$ reactions such as (R8) are not major contributors to the formation of $\mathrm{HO}_{2}$. At early times, $\mathrm{HO}_{2}$ is produced by $\mathrm{H}+\mathrm{O}_{2}(+\mathrm{M})=\mathrm{HO}_{2}$ $(+\mathrm{M})$. At later times, $\mathrm{HO}_{2}$ is generated via the reaction $\mathrm{HCO}+\mathrm{O}_{2}=\mathrm{CO}+\mathrm{HO}_{2}$. Specifically, of the top 10 reactions that produce and consume $\mathrm{HO}_{2}$, none is an $\mathrm{R}+\mathrm{O}_{2}$ reaction.

It is important to note that even though the gas samples are quenched by rapid expansion into the sample chamber, small radicals such as $\mathrm{O}, \mathrm{H}, \mathrm{OH}, \mathrm{CH}$, and $\mathrm{CH}_{3}$ will recombine. The resulting effects on most of the species measured using the GC sampling system are limited, as the concentrations of the small radicals

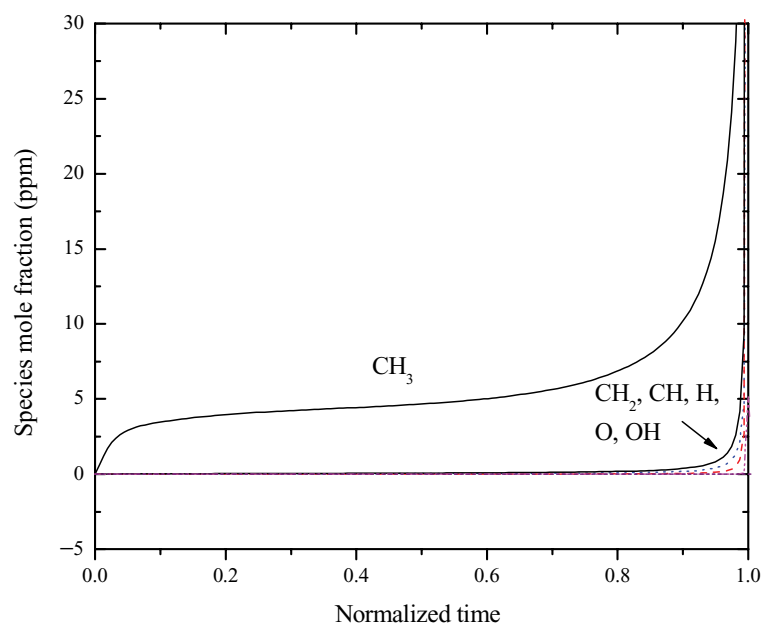

Figure 6 Predicted small radical profiles based on the isooctane reaction mechanism by Curran et al. [11] and conditions of $\phi=0.4\left(\chi_{\mathrm{i}-\mathrm{C}_{8} \mathrm{H}_{18}}=0.53 \%, \chi_{\mathrm{Ar}}=9.8 \%\right.$, $\left.\chi_{\mathrm{O}_{2}}=16.6 \%, \chi_{\mathrm{N}_{2}}=73.1 \%\right), P=5.2 \mathrm{~atm}$, and $T=1000 \mathrm{~K}$. [Color figure can be viewed in the online issue, which is available at www.interscience.wiley.com.]

are generally low, as seen in Fig. 6. However, recombination can play a larger role at times closer to ignition for $\mathrm{HC}$ and oxygenate species measured at levels on the order of $10 \mathrm{ppm}$.

In general, the sensitivity to the different equivalence ratios was consistent between the model predictions and the experimental data. For example, the measured values for $\mathrm{i}-\mathrm{C}_{4} \mathrm{H}_{8}$ and the four $\mathrm{C}_{4} \mathrm{H}_{7}$ isomers increased significantly for the $\phi=1.2$ conditions compared to the $\phi=0.4$ conditions. The simulations showed similar sensitivity. For some species, such as $\mathrm{j}-\mathrm{C}_{8} \mathrm{H}_{16}$ and $\mathrm{i}-\mathrm{C}_{8} \mathrm{H}_{16}$, the magnitude of the increase in the predicted values was higher than observed experimentally. Acetone was the only species where the simulations indicated a significant increase in the species time history for $\phi=1.2$, where the experimental data showed no sensitivity to the change in conditions.

\section{Oxygenated Hydrocarbons}

Experimental results showed that acetaldehyde $\left(\mathrm{CH}_{3} \mathrm{CHO}\right)$, acetone $\left(\mathrm{CH}_{3} \mathrm{COCH}_{3}\right)$, and methacrolein $\left(\mathrm{i}-\mathrm{C}_{3} \mathrm{H}_{5} \mathrm{CHO}\right)$ were the oxygenate species formed at the highest levels of those measured (on the order of $100 \mathrm{ppm}$ at the conditions studied; see Figs. 4v, 4w, and $4 \mathrm{bb}$ ). In the mechanism assembled by Curran et al. [11], both acetone and acetaldehyde are predicted using the Waddington mechanism. The model predictions are in very good agreement for these species for the lean condition and for acetaldehyde at the fuel-rich conditions. However, as noted earlier, the model predicts an increase in acetone production at the fuel-rich condition, 
whereas no differences are observed in the lean and rich experimental profiles.

Methacrolein is predicted to be formed primarily by the decomposition of methallyl-oxyl radical $\left(\mathrm{i}-\mathrm{C}_{4} \mathrm{H}_{7} \mathrm{O}\right)$ :

$$
\text { i- } \mathrm{C}_{4} \mathrm{H}_{7} \mathrm{O} \rightarrow \mathrm{i}-\mathrm{C}_{3} \mathrm{H}_{5} \mathrm{CHO}+\mathrm{H}
$$

The model predictions are higher than the experimental data, particularly at times closed to ignition.

Other oxygenates were quantified including propionaldehyde $\left(\mathrm{C}_{3} \mathrm{H}_{6} \mathrm{O} 1-2\right)$, isobutyraldehyde (i$\left.\mathrm{C}_{3} \mathrm{H}_{7} \mathrm{CHO}\right)$, allyl alcohol $\left(\mathrm{C}_{3} \mathrm{H}_{5} \mathrm{OH}\right)$, and 2-methyl2-propen-1-ol (i- $\mathrm{C}_{4} \mathrm{H}_{7} \mathrm{OH}$ ) (see Figs. 4x, 4y, 4aa, and $4 \mathrm{cc})$. These species were well reproduced by the model predictions, with the exception of i- $\mathrm{C}_{4} \mathrm{H}_{7} \mathrm{OH}$. The experimental data for i- $\mathrm{C}_{4} \mathrm{H}_{7} \mathrm{OH}$ were below $25 \mathrm{ppm}$ for all times and conditions, whereas the model predictions indicated peak values in excess of $150 \mathrm{ppm}$.

Propionaldehyde was predicted to be formed from the reactions of propene with hydroperoxide radical:

$$
\mathrm{C}_{3} \mathrm{H}_{6}+\mathrm{HO}_{2} \rightarrow \mathrm{C}_{3} \mathrm{H}_{6} \mathrm{O} 1-2+\mathrm{OH}
$$

and the decomposition reactions of $\mathrm{C}_{3} \mathrm{H}_{6} \mathrm{OOH} 2-1$ :

$$
\mathrm{C}_{3} \mathrm{H}_{6} \mathrm{OOH} 2-1 \rightarrow \mathrm{C}_{3} \mathrm{H}_{6} \mathrm{O} 1-2+\mathrm{OH}
$$

and $\mathrm{C}_{3} \mathrm{H}_{6} \mathrm{OOH} 1-2$ :

$$
\mathrm{C}_{3} \mathrm{H}_{6} \mathrm{OOH} 1-2 \rightarrow \mathrm{C}_{3} \mathrm{H}_{6} \mathrm{O} 1-2+\mathrm{OH}
$$

Isobutyraldehyde is formed primarily via the isomerization of isobutylene oxide $\left(\mathrm{i}-\mathrm{C}_{4} \mathrm{H}_{8} \mathrm{O}\right)$ :

$$
\text { i- } \mathrm{C}_{4} \mathrm{H}_{8} \mathrm{O} \rightarrow \mathrm{i}-\mathrm{C}_{3} \mathrm{H}_{7} \mathrm{CHO}
$$

Isobutylene oxide is formed by the reaction of isobutene with the hydroperoxide radical:

$$
\text { i- } \mathrm{C}_{4} \mathrm{H}_{8}+\mathrm{HO}_{2} \rightarrow \text { i- } \mathrm{C}_{4} \mathrm{H}_{8} \mathrm{O}+\mathrm{OH}
$$

Good agreement was observed between the measured and predicted profiles for isobutyraldehyde, and reasonable agreement was observed for isobutylene oxide considering the larger experimental uncertainties associated with $\mathrm{i}-\mathrm{C}_{4} \mathrm{H}_{8} \mathrm{O}$.

Significant quantities of carbon monoxide (CO) were formed during the ignition delay period (see Fig. 4a). Very good agreement was observed between the experimental and modeling results at both experimental conditions. $\mathrm{CO}$ is primarily generated via the reaction of formyl radical $(\mathrm{HCO})$ with $\mathrm{O}_{2}$.

\section{Comparison with Previous Work}

The results of this study are in good agreement with the flow reactor studies of Chen et al. [10] in terms of the major species identified. Although Chen et al. [10] studied very lean mixtures $(\phi=0.05)$, at $T=915-$ $950 \mathrm{~K}, P=3,6$, and 9 atm, this work confirms the same general reaction path sequence identified in their work at intermediate temperatures, where isooctane is primarily consumed by the $\mathrm{H}$-atom abstraction. The isooctyl radicals undergo $\beta$-scission to form olefin and alkyl radical species. For both studies, the major intermediates were $\mathrm{i}-\mathrm{C}_{4} \mathrm{H}_{8}, \mathrm{C}_{3} \mathrm{H}_{6}, \mathrm{CH}_{4}$, and $\mathrm{CO}$. A slightly different ranking of the $\mathrm{C} 7$ olefins was observed in this work, where y- $\mathrm{C}_{7} \mathrm{H}_{14}>\mathrm{x}-\mathrm{C}_{7} \mathrm{H}_{14}, \mathrm{o}-\mathrm{C}_{7} \mathrm{H}_{14}>\mathrm{p}-\mathrm{C}_{7} \mathrm{H}_{14}$, compared to $\mathrm{y}-\mathrm{C}_{7} \mathrm{H}_{14}, \mathrm{o}-\mathrm{C}_{7} \mathrm{H}_{14}>\mathrm{x}-\mathrm{C}_{7} \mathrm{H}_{14}>\mathrm{p}-\mathrm{C}_{7} \mathrm{H}_{14}$ observed in Chen et al. [10]. The same major oxygenates were observed in the two studies, $\mathrm{CH}_{3} \mathrm{COCH}_{3}$ and $\mathrm{i}-\mathrm{C}_{3} \mathrm{H}_{5} \mathrm{CHO}$.

The results of the current work are also in good agreement with the jet-stirred reactor (JSR) study by Dagaut et al. [3] in terms of the species observed and relative concentrations of the major species. Note that the results of Dagaut and coworkers are presented as a function of JSR temperature and $\phi$, with results for $\phi=0.3$ and $\phi=0.5$ and with limited data available at $T=1000 \mathrm{~K}$ and higher. Dagaut et al. observed a different ranking of the $\mathrm{C} 7$ olefins o- $\mathrm{C}_{7} \mathrm{H}_{14}>\mathrm{y}-\mathrm{C}_{7} \mathrm{H}_{14},>$ p- $\mathrm{C}_{7} \mathrm{H}_{14}>\mathrm{x}-\mathrm{C}_{7} \mathrm{H}_{14}$, compared to this work and the study by Chen et al., which may be an indication of stronger sensitivity to the location of the $\mathrm{H}$-atom abstraction to the experimental conditions than previously anticipated in the reaction mechanism. This site sensitivity could be the source of the discrepancies observed with some of the $\mathrm{C} 4$ and $\mathrm{C} 5$ species (e.g., $1-\mathrm{C}_{4} \mathrm{H}_{8}$ and $\mathrm{a}-\mathrm{C}_{5} \mathrm{H}_{10}$ ) that are formed by the reaction involving the fragments of $\beta$-scission of the isooctyl radicals. Given the remarkably different experimental methods used in the current work and the studies by Chen et al. and Dagaut et al., the level of agreement between the studies gives high credibility to the species identified and the quantities measured.

\section{Sensitivity Analysis}

Sensitivity analysis was conducted for several $\mathrm{HC}$ species (e.g., a- $\mathrm{C}_{5} \mathrm{H}_{10}, \mathrm{C}_{2} \mathrm{H}_{6}, \mathrm{C}_{3} \mathrm{H}_{6}, \mathrm{i}-\mathrm{C}_{3} \mathrm{H}_{5} \mathrm{CHO}$ ) at the lean experimental conditions, in which the normalized sensitivity coefficient is defined as

$$
S_{j, i}=\frac{\partial \chi_{j}}{\partial k_{i}} \cdot \frac{k_{i}}{\left(\chi_{j}\right)_{\text {local }}}
$$

where $\chi_{j}$ is the mole fraction of species $j$ and $k_{i}$ is the rate coefficient of reaction $i$. The results identified 


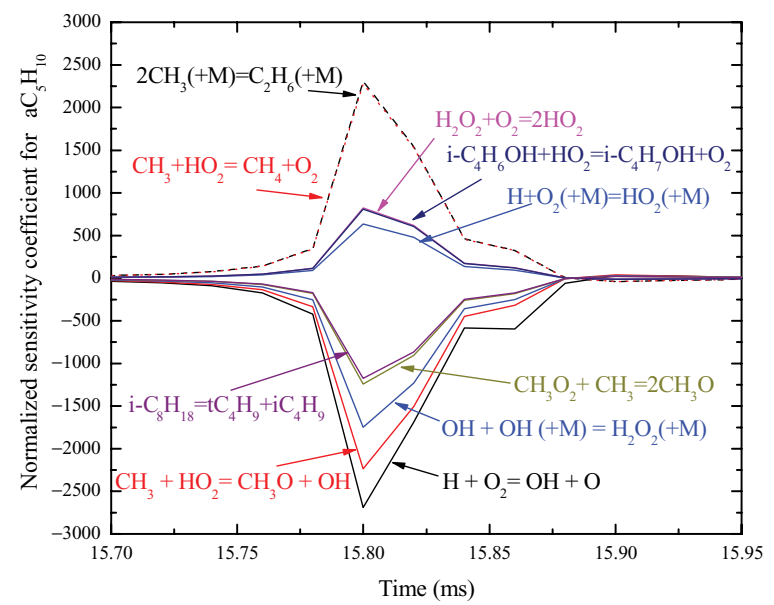

Figure 7 Sensitivity analysis for a- $\mathrm{C}_{5} \mathrm{H}_{10}$ based on the isooctane reaction mechanism developed by Curran et al. [11]. Experimental conditions are $\phi=0.4\left(\chi_{\mathrm{i}-\mathrm{C}_{8} \mathrm{H}_{18}}=0.53 \%\right.$, $\left.\chi_{\mathrm{Ar}}=9.8 \%, \chi_{\mathrm{O}_{2}}=16.6 \%, \chi_{\mathrm{N}_{2}}=73.1 \%\right), P=5.2 \mathrm{~atm}$, and $T=1000 \mathrm{~K}$. [Color figure can be viewed in the online issue, which is available at www.interscience.wiley.com.]

the same key reactions for all species evaluated; therefore, only representative results for $\mathrm{a}-\mathrm{C}_{5} \mathrm{H}_{10}$ are shown in Fig. 7. The sensitivity analysis indicates that the primary reactions controlling the ignition profiles are

$$
\begin{aligned}
\mathrm{CH}_{3}+\mathrm{CH}_{3}(+\mathrm{M}) & =\mathrm{C}_{2} \mathrm{H}_{6}(+\mathrm{M}) \\
\mathrm{CH}_{3}+\mathrm{HO}_{2} & =\mathrm{CH}_{4}+\mathrm{O}_{2} \\
\mathrm{H}+\mathrm{O}_{2} & =\mathrm{OH}+\mathrm{O} \\
\mathrm{CH}_{3}+\mathrm{HO}_{2} & =\mathrm{CH}_{3} \mathrm{O}+\mathrm{OH} \\
\mathrm{OH}+\mathrm{OH}(+\mathrm{M}) & =\mathrm{H}_{2} \mathrm{O}_{2}(+\mathrm{M})
\end{aligned}
$$

The same reactions were identified as critical to $\mathrm{OH}$ profiles during isooctane ignition studies conducted at similar conditions by $\mathrm{He}$ et al. [15]. In the study by $\mathrm{He}$ et al. [15], sensitivity of the $\mathrm{OH}$ time histories and the ignition delay time to the $\mathrm{CH}_{3}+\mathrm{HO}_{2}$ reactions ((R29) and (R31)) was investigated. These reactions have relatively high uncertainties and because of the critical role $\mathrm{CH}_{3}$ plays in the $\mathrm{HC}$ kinetics, changing the rate coefficient to these reactions affects some of the species time histories considered in this work. Specifically, increasing the rate coefficients for (R29) and (R31) yields a lower overall $\mathrm{C}_{2} \mathrm{H}_{6}$ profile, due to decreased $\mathrm{CH}_{3}$ concentrations, and a higher overall allene $\left(\mathrm{a}-\mathrm{C}_{3} \mathrm{H}_{4}\right)$ profile, due to decreased $\mathrm{HO}_{2}$ concentrations. Since the hydroperoxide radical is one of the major reactants to form propionaldehyde $\left(\mathrm{C}_{3} \mathrm{H}_{6} \mathrm{O} 1-2\right)$, increasing the rate coefficients of (R29) and (R31) results in a decrease in propionaldehyde formation. Predicted i- $\mathrm{C}_{4} \mathrm{H}_{8} \mathrm{O}$ and acetone profiles are similarly reduced in magnitude when (R29) and (R31) are increased. All other species considered were unaffected by changes to these rate coefficients.

\section{SUMMARY AND CONCLUSIONS}

New species mole fraction data were obtained for better understanding of isooctane oxidation in the intermediate temperature region. Thirty hydrocarbon and oxygenate intermediate species were identified and quantified. The experimental data were used to evaluate the performance of the detailed isooctane reaction mechanism developed by Curran et al. [11]. In general, there was excellent agreement, well within a factor of 2 for most species, between the model predictions and the experimental data for major and minor compounds. The most notable exceptions were those for $\mathrm{C}_{4} \mathrm{H}_{6}$, which was significantly underpredicted by the model, and $\mathrm{o}-\mathrm{C}_{7} \mathrm{H}_{14}$ and $\mathrm{i}-\mathrm{C}_{4} \mathrm{H}_{7} \mathrm{OH}$, which were significantly overpredicted by the model. The results indicate that there may be alternative $\mathrm{C}_{4} \mathrm{H}_{6}$ reaction pathways that are not captured by the current reaction mechanism. The experimental results were in very good agreement-with respect to the species identified and the relative levels-with the previous flow reactor study of isooctane oxidation by Chen et al. [10], thereby supporting the proposed mechanism for isooctane oxidation in the intermediate temperature regime. The current work also successfully demonstrates the use of the UM RCF with gas sampling as a robust means to obtain quantitative data on the intermediates of combustion. This method can be applied to a broad spectrum of fuel systems, at realistic concentrations of fuel and air and at pressures and temperatures directly relevant to combustion technologies. In particular, additional studies of key fuel compounds at low temperatures, including the important negative temperature coefficient region, are of considerable interest.

We would like to thank Dr. William Pitz at Lawrence Livermore National Laboratory for his assistance with the sensitivity analysis.

\section{BIBLIOGRAPHY}

1. Vermeer, D. J.; Meyer, J. W.; Oppenheim, A. K. Combust Flame 1972, 18, 327-336.

2. Griffiths, J. F.; Halford-Maw, P. A.; Rose, D. J. Combust Flame 1993, 95, 291-306. 
3. Dagaut, P.; Reuillon, M.; Cathonnet, M. Combust Sci Technol 1994, 95, 233-260.

4. Callahan, C. V.; Held, T. J.; Dryer, F. L.; Minetti, R.; Ribaucour, M.; Sochet, L. R.; Faravelli, T.; Gaffuri, P.; Ranzi, E. Proc Combust Inst 1996, 26, 739746.

5. Minetti, R.; Carlier, M.; Ribaucour, M.; Therssen, E.; Sochet, L. R. Proc Combust Inst 1996, 26, $747-$ 753.

6. Côme, G. M.; Warth, V.; Glaude, P. A.; Fournet, R.; Battin-Leclerc, F.; Scacchi, G. Proc Combust Inst 1996, 26, 755-762.

7. Minetti, R.; Ribaucour, M.; Carlier, M.; Sochet, L. R. Combust Sci Technol 1996, 113-114, 179-192.

8. Ranzi, E.; Faravelli, T.; Gaffuri, P.; Sogaro, A.; D’Anna, A.; Ciajolo. A. Combust Flame 1997, 108, 24-42.

9. Fieweger, K.; Blumenthal, R.; Adomeit, G. Combust Flame 1997, 109, 599-619.

10. Chen, J.-S.; Litzinger, T. A.; Curran, H. J. Combust Sci Technol 2000, 156, 49-79.

11. Curran, H. J.; Gaffuri, P.; Pitz, W. J.; Westbrook, C. K. Combust Flame 2002, 129, 253-280.

12. Tanaka, S.; Ayala, F.; Keck, J. C. Combust Flame 2003, 133, 467-481.

13. Davidson, D. F.; Gauthier, B. M.; Hanson, R. K. Proc Combust Inst 2005, 30, 1175-1182.

14. He, X.; Donovan, M. T.; Zigler, B. T.; Palmer, T. R.; Walton, S. M.; Wooldridge, M. S.; Atreya, A. Combust Flame 2005, 142, 266-275.

15. He, X.; Zigler, B. T.; Walton, S. M.; Wooldridge, M. S.; Atreya, A. Combust Flame 2006, 145, 552570.

16. Kahandawala, M. S. P.; Corera, S. A. P.; Williams, S.; Carter, C. D.; Sidhu, S. S. Int J Chem Kinet 2006, 38, 194-201.

17. Glaude, P. A.; Conraud, V.; Fournet, R.; Battin-Leclerc, F.; Côme, G. M.; Scacchi, G.; Dagaut, P.; Cathonnet, M. Energy Fuels 2002, 16, 1186-1195.
18. Minetti, R.; Carlier, M.; Ribaucour, M.; Therssen, E.; Sochet, L. R. Combust Flame 1995, 102, 298-309.

19. Gauthier, B. M.; Davidson, D. F.; Hanson, R. K. Combust Flame 2004, 139, 300-311.

20. Ranzi, E.; Gaffuri, P.; Faravelli, T.; Dagaut, P. Combust Flame 1995, 103, 91-106.

21. Davidson, D. F.; Oehlschlaeger, M. A.; Herbon, J. T.; Hanson, R. K. Proc Combust Inst 2002, 29, 1295-1301.

22. Oehlschlaeger, M. A.; Davidson, D. F.; Herbon, J. T.; Hanson, R. K. Int J Chem Kinet 2003, 36, 67-78.

23. Park, P.; Keck, J. C. SAE paper no. 900027, 1990.

24. Cox, A.; Griffiths, J. F.; Mohamed, C.; Curran, H. J.; Pitz, W. J.; Westbrook, C. K. Proc Combust Inst 1996, 26, 2685-2692.

25. D'Anna, A.; Mercogliano, R.; Barbella, R.; Ciajolo, A. Combust Sci Technol 1992, 83, 217-232.

26. Dryer, F. L.; Brezinsky, K. Combust Sci Technol 1986, 45, 199-212.

27. Donovan, M. T.; He, X.; Zigler, B. T.; Palmer, T. R.; Wooldridge, M. S.; Atreya, A. Combust Flame 2004, 137, 351-365.

28. Donovan, M. T. Ph.D. dissertation, Department of Mechanical Engineering, University of Michigan, Ann Arbor, MI, 2003.

29. He, X. Ph.D. dissertation, Department of Mechanical Engineering, University of Michigan, Ann Arbor, MI, 2005.

30. McBride, B. J.; Gordon, S.; Reno, M. A. NASA Thermodynamic Data Base, NASA Technical Memorandum 4513, October 1993.

31. Kee, R. J.; Rupley, F. M.; Miller, J. A.; Coltrin, M. E.; Grcar, J. F.; Meeks, E.; Moffat, H. K.; Lutz, A. E.; DixonLewis, G. M.; Smooke, D.; Warnatz, J.; Evans, G. H.; Larson, R. S.; Mitchell, R. E.; Petzold, L. R.; Reynolds, W. C.; Caracotsios, M.; Stewart, W. E.; Glarborg, P.; Wang, C.; Adigun, O.; Houf, W. G.; Chou, C. P.; Miller, S. F.; Ho, P.; Young, D. J. CHEMKIN Release 4.0, Reaction Design, Inc., San Diego, CA, 2004. 